\title{
Article \\ Ethanol Sensing Properties and First Principles Study of Au Supported on Mesoporous ZnO Derived from Metal Organic Framework ZIF-8
}

\author{
Yanli Kang ${ }^{1}$, Lu Zhang ${ }^{2}$, Wenhao Wang ${ }^{1}$ and Feng Yu ${ }^{1, * \mathbb{D}}$ \\ 1 Key Laboratory for Green Processing of Chemical Engineering of Xinjiang Bingtuan, School of Chemistry and \\ Chemical Engineering, Shihezi University, Shihezi 832003, China; 13040547128@163.com (Y.K.); \\ 18299083557@163.com (W.W.) \\ 2 School of Science, Harbin Institute of Technology, Shenzhen 518055, China; 18B925124@stu.hit.edu.cn \\ * Correspondence: yufeng05@mail.ipc.ac.cn
}

check for

updates

Citation: Kang, Y.; Zhang, L.; Wang, W.; Yu, F. Ethanol Sensing Properties and First Principles Study of $\mathrm{Au}$ Supported on Mesoporous $\mathrm{ZnO}$ Derived from Metal Organic Framework ZIF-8. Sensors 2021, 21, 4352. https://doi.org/10.3390/ s21134352

Academic Editor: Nandika

Anne D'Souza

Received: 14 May 2021

Accepted: 23 June 2021

Published: 25 June 2021

Publisher's Note: MDPI stays neutral with regard to jurisdictional claims in published maps and institutional affiliations.

Copyright: (c) 2021 by the authors. Licensee MDPI, Basel, Switzerland. This article is an open access article distributed under the terms and conditions of the Creative Commons Attribution (CC BY) license (https:// creativecommons.org/licenses/by/ $4.0 /)$.

\begin{abstract}
It is of great significance to develop ethanol sensors with high sensitivity and low detection temperature. Hence, we prepared Au-supported material on mesoporous $\mathrm{ZnO}$ composites derived from a metal-organic framework ZIF-8 for the detection of ethanol gas. The obtained $\mathrm{Au} / \mathrm{ZnO}$ materials were characterized by X-ray diffraction (XRD), X-ray photoelectron spectroscopy (XPS), field emission scanning electron microscopy (SEM), field emission transmission electron microscopy (TEM) and nitrogen adsorption and desorption isotherms. The results showed that the $\mathrm{Au} / \mathrm{ZnO}-1.0$ sample maintains a three-dimensional (3D) dodecahedron structure with a larger specific surface area $\left(22.79 \mathrm{~m}^{2} \mathrm{~g}^{-1}\right)$ and has more oxygen vacancies. Because of the unique ZIF structure, abundant surface defects and the formation of $\mathrm{Au}-\mathrm{ZnO}$ Schottky junctions, an $\mathrm{Au} / \mathrm{ZnO}-1.0$ sensor has a response factor of 37.74 for $100 \mathrm{ppm}$ ethanol at $250{ }^{\circ} \mathrm{C}$, which is about 6 times that of pure $\mathrm{ZnO}$ material. In addition, the $\mathrm{Au} / \mathrm{ZnO}-1.0$ sensor has good selectivity for ethanol. According to density functional theory (DFT) calculations, the adsorption energy of $\mathrm{Au} / \mathrm{ZnO}$ for ethanol $(-1.813 \mathrm{eV})$ is significantly greater than that of pure $\mathrm{ZnO}(-0.217 \mathrm{eV})$. Furthermore, the adsorption energy for ethanol is greater than that of other gases.
\end{abstract}

Keywords: gas sensor; zinc oxide; gold nanoparticles; ethanol; density functional theory

\section{Introduction}

In recent years research based on ethanol $\left(\mathrm{C}_{2} \mathrm{H}_{5} \mathrm{OH}\right)$ detection has received widespread attention due to its application in various fields such as detection of chemical plant leaks and the monitoring of drunk driving. $\mathrm{C}_{2} \mathrm{H}_{5} \mathrm{OH}$, as a flammable volatile organic compound, is widely used in the food and beverage industry, medical industry and chemical industry [1]. When the air contains high concentrations of ethanol, it will cause safety accidents such as explosions [2], and cause health problems such as neurasthenia [3]. Although great progress has been made in the detection of ethanol, the present detection approaches still have shortcomings such as high operating temperature, low sensitivity and limited selectivity. Hence, more and more attention has been paid to the research of materials for high-performance ethanol detection. Modification of materials through the functionalization of precious metals is an effective strategy to improve the response of gas detection [4-6]. For example, doping $\mathrm{Au}$ in the $\mathrm{ZnO} / \mathrm{Zn}_{2} \mathrm{SnO}_{4}$ structure could increase the gas sensitivity to $\mathrm{H}_{2} \mathrm{~S}$ from 2.1 to 15.92 at $150{ }^{\circ} \mathrm{C}$ [7]. Moreover, the modification of Pd on $\mathrm{ZnO}$ can promote the dissociation of oxygen molecules to form oxygen anions, thereby increasing the sensor's response to hydrogen from 0.11 to 123.53 [8].

The high catalytic activity of precious metals can promote the decomposition of gaseous substances, which is conducive to enhancing gas sensitivity $[9,10]$. In addition, the presence of precious metals on the surface of metal oxides increases the interaction 
between reducing gases and adsorbed oxygen on the surface [11]. However, precious metals have high surface energy and are easy to agglomerate, resulting in a decrease in the catalytic performance of the material. Therefore, it is necessary to develop convenient and reliable methods to precisely control the decoration and positioning of precious metal nanoparticles on the semiconductor surface. Metal-organic frameworks (MOFs) are often used as templates because of their higher specific surface area and ordered pore size (e.g., the pore size of zeolitic imidazolate framework (ZIF-8) is about $0.34 \mathrm{~nm}$ ) [12]. MOFs can not only provide more active sites but also adjust the size of precious metal particles loaded on the surface of the material [13]. Encapsulating precious metal particles in the MOFs framework can effectively limit the size of precious metals to within a few nanometers and improve their dispersion and stability in semiconductors. As a result, the catalytic abilities of the precious metal particles in the system have been improved to a large extent [14].

In this work, with ZIF-8 as the precursor template, a three-dimensional (3D) $\mathrm{ZnO}$ structure supported by highly dispersed Au particles was prepared, which improved the sensing performance of $\mathrm{C}_{2} \mathrm{H}_{5} \mathrm{OH}$ effectively. The influence of different Au supported on the surface of $\mathrm{ZnO}$ on the detection of $\mathrm{C}_{2} \mathrm{H}_{5} \mathrm{OH}$ was discussed. The response factor (37.74 at $100 \mathrm{ppm}$ ) of the $\mathrm{Au} / \mathrm{ZnO}$ (load: $1.79 \mathrm{wt} . \%$ ) material derived from $\mathrm{Au} / \mathrm{ZIF}-8$ is six times that of pure $\mathrm{ZnO}$ material, and the response/recovery time is about $19 / 9 \mathrm{~s}$. Finally, density functional theory (DFT) was used to estimate the adsorption energy of the $\mathrm{Au} / \mathrm{ZnO}$ configuration for different gases. This shows that the sensor has great application potential in $\mathrm{C}_{2} \mathrm{H}_{5} \mathrm{OH}$ detection.

\section{Materials and Methods}

\subsection{Chemicals}

All chemicals are analytically pure and can be used directly without further purification. 1,2-Dimethylimidazole, sodium borohydride $(\mathrm{NaBH}, 98.0 \%)$ and hydrogen tetrachloroaurate trihydrate $\left(\mathrm{HAuCl}_{4} \cdot 3 \mathrm{H}_{2} \mathrm{O}, 99.9 \%\right)$ were from Shanghai Adamas Reagent Co., Ltd, China. Zinc acetate dihydrate $\left(\mathrm{C}_{4} \mathrm{H}_{6} \mathrm{O}_{4} \mathrm{Zn} \cdot 2 \mathrm{H}_{2} \mathrm{O}, 99.0 \%\right)$ was purchased from Shanghai Titan Technology Co., Ltd., (Greagent), China. Methanol $\left(\mathrm{CH}_{3} \mathrm{OH}, 99.9 \%\right)$ and $\mathrm{C}_{2} \mathrm{H}_{5} \mathrm{OH}(99.7 \%)$ were from Tianjin Fuyu Fine Chemical Co., Ltd., China, and homemade deionized water.

\subsection{Preparation of ZIF-8 Materials}

The preparation of ZIF- 8 adopted a simple co-precipitation method. We prepared clear solution 1 containing $\mathrm{C}_{4} \mathrm{H}_{6} \mathrm{O}_{4} \mathrm{Zn} \cdot 2 \mathrm{H}_{2} \mathrm{O}(3.81 \mathrm{~g})$ and $200 \mathrm{~mL} \mathrm{CH} \mathrm{CH}_{3} \mathrm{OH}$. 1,2-dimethylimidazole $(9.25 \mathrm{~g})$ and $200 \mathrm{~mL}$ of $\mathrm{CH}_{3} \mathrm{OH}$ were used to prepare clear solution 2. At room temperature, solution 2 was slowly added dropwise to solution 1, and then the mixed solution was continuously stirred for $24 \mathrm{~h}$. During the stirring process, it was observed that white precipitates gradually appeared. Subsequently, the white precipitates (ZIF-8) were collected by centrifugation, washing with $\mathrm{CH}_{3} \mathrm{OH} 5$ times, and vacuum drying at $60^{\circ} \mathrm{C}$ for $12 \mathrm{~h}$.

\subsection{Preparation of Au Supported $\mathrm{ZnO}$ Materials}

Prepared ZIF-8 powder $(0.1 \mathrm{~g})$ was put into $\mathrm{CH}_{3} \mathrm{OH}(5 \mathrm{~mL})$ and agitated for $2 \mathrm{~h}$ to ensure uniform dispersion. We then added $1 \mathrm{~mL}$ of chloroauric acid aqueous solution $(1 \mathrm{mg} / \mathrm{mL})$ to the precursor solution and continued to stir for $1 \mathrm{~h}$. In the above solution, an appropriate amount of $\mathrm{NaBH}(1.5 \mathrm{mg} / \mathrm{mL})$ was added drop by drop and kept stirring for $2 \mathrm{~h}$. The color of the solution (yellow) had a transition to purple in the process of $\mathrm{NaBH}$ solution addition, which indicated the transition from $\mathrm{Au}^{3+}$ to $\mathrm{Au}^{0}$. Finally, the purple suspension was washed with $\mathrm{CH}_{3} \mathrm{OH}$ and centrifuged for 3 cycles. The Au/ZIF-8 purple powder was obtained by drying under vacuum at $60{ }^{\circ} \mathrm{C}$ for $12 \mathrm{~h}$. It was calcined at a rate of $10^{\circ} \mathrm{C} / \mathrm{min}$ to $500^{\circ} \mathrm{C}$ for $2 \mathrm{~h}$ in a muffle furnace and then cooled naturally to room temperature to obtain the sample $\mathrm{Au} / \mathrm{ZnO}-1.0$. By adjusting the dropping amount of the chloroauric acid aqueous solution, $\mathrm{ZnO}$ with different amounts of $\mathrm{Au}$ modification was obtained. The obtained samples were named $\mathrm{Au} / \mathrm{ZnO}-0.5$ and $\mathrm{Au} / \mathrm{ZnO}-1.5$ by dropping 
$0.5 \mathrm{~mL}$ and $1.5 \mathrm{~mL}$ chloroauric acid aqueous solution, respectively. For comparative analysis, the ZIF-8 powder was directly calcined in a muffle furnace to obtain the comparative sample $\mathrm{ZnO}$.

\subsection{Gas Sensing Measurements}

Metal oxide gas sensors are usually divided into two categories: indirect heating and direct heating, among which indirect gas sensors are used in this work. The synthesized material is mixed with a small amount of ethanol, and the mixed solution is coated on the ceramic tube substrate with a sample pen to form a thin and uniform coating of the sensing material. Then, in order to control the working temperature, the nickel-chromium coil is passed through the ceramic tube as a heater. Subsequently, the platinum wire and nickel-chromium heating wire pre-installed on the ceramic tube is welded to the base of the gas sensor. In order to improve the stability and repeatability of these sensor elements, the prepared sensor elements were aged at $170^{\circ} \mathrm{C}$ for $24 \mathrm{~h}$ on an aging table. The gas sensor measurement is carried out using the CGS-8 intelligent gas sensor analysis system (Beijing Elite Technology Co., Ltd., Beijing, China) at an ambient temperature and relative humidity of $30{ }^{\circ} \mathrm{C}$ and $25-30 \%$. In the process of testing, all the gases required in the test process adopt the liquid evaporation method. The response factor $(S)$ of a material is defined as the ratio of the resistance $\left(R_{a}\right)$ of the gas-sensitive material in the air to the resistance $\left(R_{g}\right)$ in the target gas.

\subsection{Material Characterization}

X-ray diffraction (XRD, BRUCKER D8 ADVANCE, Berlin, Germany) provided a diffraction pattern of $10-80^{\circ}$ diffraction range for analyzing the phase composition and crystal structure of the product. The Au content in different samples was determined by an inductively coupled plasma atomic emission spectrometer (ICP, Agilent ICPOES730, San-ta Clara, CA, USA). The morphology and structural characteristics of the samples were observed using a field emission scanning electron microscope (FE-SEM, SU-8020, Hitachi Corporation, Tokyo, Japan) and a field emission transmission electron microscope (TEM, JEM 2100F, JEOL Ltd., Tokyo, Japan). X-ray photoelectron spectroscopy (XPS, Thermo escalab 250Xi, Thermo Fisher Scientific, Waltham, MA, USA) was used to measure the chemical composition and valence state of the product elements. The specific surface area of the materials was measured by the physical adsorption instrument (ASAP 2460, Micromeritics instrument Ltd., Norcross, GA, USA) and the BET model, while the pore size distribution was calculated using the Barrett-Joyner-Halenda $(\mathrm{BJH})$ method. An electron paramagnetic resonance (EPR, A300-10/12 Bruker, Berlin, Germany) test was used for quantitative analysis of oxygen vacancy.

\section{Results and Discussion}

\subsection{Morphology and Structure of ZIF-8 Derived Au/ZnO Samples}

Figure 1a is the $\mathrm{X}$-ray diffraction pattern of the prepared $\mathrm{ZnO}$ materials with different Au capacities. The profile of ZIF-8 is consistent with previous reports [15] proving that ZIF-8 was successfully synthesized. The diffraction peaks of pure $\mathrm{ZnO}$ at $2 \theta=31.77^{\circ}$, $34.42^{\circ}, 36.25^{\circ}, 47.54^{\circ}, 56.60^{\circ}, 62.86^{\circ}$ and $67.96^{\circ}$, which correspond to the reflection of (100), (002), (101), (102), (110), (103) and (112) crystal planes of wurtzite ZnO (PDF\#36-1451). The figure on the right is the partially enlarged XRD diffraction pattern of $\mathrm{ZnO}$ loaded with different Au content, which shows that the peak shape of Au becomes more and more obvious as the $\mathrm{Au}$ load increases. When the added amount of $\mathrm{Au}$ reaches $1.0 \mathrm{~mL}$, the XRD peak near $38.18^{\circ}$ matches the (111) crystal plane of Au (PDF\#04-0784), which proves that the synthesis of $\mathrm{Au} / \mathrm{ZnO}$ composites is successful. When the Au added amount is $0.5 \mathrm{~mL}$, no Au diffraction peaks are found, which is the reason for the low Au content or the uniform Au loading distribution [16]; this is also consistent with the ICP results (Table S1). The actual content of $\mathrm{Au}$ in the $\mathrm{Au} / \mathrm{ZnO}-0.5, \mathrm{Au} / \mathrm{ZnO}-1.0$ and $\mathrm{Au} / \mathrm{ZnO}-1.5$ samples are $0.92,1.79$ and $2.98 \mathrm{wt} . \%$, respectively. 
The full XPS spectrum of as-synthesized $\mathrm{Au} / \mathrm{ZnO}$ samples shows the two main components of $\mathrm{Zn}$ and $\mathrm{O}$, as shown in Figure $1 \mathrm{~b}$. In the $\mathrm{Zn} 2 \mathrm{p}$ spectra of the sample (Figure 1c), the corresponding peaks of $\mathrm{Zn} 2 \mathrm{p}_{3 / 2}$ and $\mathrm{Zn} 2 \mathrm{p}_{1 / 2}$ are at $\sim 1044.5$ and $\sim 1021.3 \mathrm{eV}$, representing the oxidation state of $\mathrm{Zn}$ (II) [17]. The double peaks of $\mathrm{Au} 4 \mathrm{f}$ in Figure $1 \mathrm{~d}$ are located at $87.2 \mathrm{eV}$ and $83.5 \mathrm{eV}$, corresponding to the peaks of $A u 4 f_{5 / 2}$ and $4 f_{7 / 2}$, respectively. The gap between $\mathrm{Au} 4 \mathrm{f}_{7 / 2}$ and $\mathrm{Au} 4 \mathrm{f}_{5 / 2}$ is consistent with the standard value $(3.7 \mathrm{eV})$ of spin-orbit doublet separation, which belongs to the $\mathrm{Au}^{0}$ characteristic, proving that $\mathrm{NaBH}$ successfully converted $\mathrm{Au}^{3+}$ into $\mathrm{Au}^{0}$ [18-20]. Compared with the binding energy of pure metal $\mathrm{Au} 4 \mathrm{f}_{7 / 2}(84.0 \mathrm{eV})$ and $4 \mathrm{f}_{5 / 2}(87.7 \mathrm{eV})$, the reason why the binding energy of $\mathrm{Au} 4 \mathrm{f}$ in $\mathrm{Au} / \mathrm{ZnO}$ materials decreased is the strong interaction between $\mathrm{Au}$ and $\mathrm{ZnO}$ [21-23]. Since the work function of $\mathrm{Au}(5.1 \mathrm{eV})$ [24] is higher than that of $\mathrm{ZnO}(4.45 \mathrm{eV})$ [16], electrons are transferred from $\mathrm{ZnO}$ to $\mathrm{Au}$ nanoparticles when Au nanoparticles contact $\mathrm{ZnO}$. $\mathrm{Zn}$ $3 p_{1 / 2}$ and $Z n 3 p_{3 / 2}$ are two interference peaks among the four peaks. Generally speaking, oxygen vacancies and chemisorbed oxygen species play an important role in gas sensing performance. Hence, we have performed deconvolution on the $\mathrm{O} 1$ s peaks of $\mathrm{ZnO}$ and $\mathrm{Au} / \mathrm{ZnO}-1.0$ materials (Figure 1e,f). The $\mathrm{O} 1 \mathrm{~s}$ peak of pure $\mathrm{ZnO}$ can be divided into three peaks: $531.9 \mathrm{eV}\left(\mathrm{O}_{\mathrm{C}}\right), 530.7 \mathrm{eV}\left(\mathrm{O}_{\mathrm{V}}\right)$ and $530.2 \mathrm{eV}\left(\mathrm{O}_{\mathrm{L}}\right)$. The $\mathrm{O}_{\mathrm{L}}$ peak with the lowest binding energy comes from the lattice oxygen on the hexagonal wurtzite structure, and the $\mathrm{O}_{\mathrm{V}}$ peak represents the oxygen vacancies in the $\mathrm{ZnO}$ and $\mathrm{Zn}-\mathrm{OH}$ matrix. The $\mathrm{O}_{\mathrm{C}}$ peak with the highest binding energy usually represents the weaker oxygen adsorption on the surface of the $\mathrm{ZnO}$ material, such as $\mathrm{H}_{2} \mathrm{O}$ or $\mathrm{O}_{2}$ [25]. For the $\mathrm{Au} / \mathrm{ZnO}-1.0$ sample, it can be seen from Figure 1e that there is no obvious shift in the peak positions of $\mathrm{O}_{C}$, $\mathrm{O}_{\mathrm{V}}$ and $\mathrm{O}_{\mathrm{L}}$. The difference is the $\mathrm{O}_{\mathrm{V}}$ peak area ratio of $\mathrm{Au} / \mathrm{ZnO}$ is about $38.99 \%$ higher than that of pure $\mathrm{ZnO}(30.96 \%)$, which is consistent with the result of EPR (Figure S1). The modification of $\mathrm{Au}$ nanoparticles can increase the $\mathrm{O}_{\mathrm{V}}$ content in $\mathrm{ZnO}$ materials, which can be attributed to the "spillover effect" of precious metals $[26,27]$. The increase of $\mathrm{O}_{V}$ can generate more free electrons, which will enhance the adsorption of surface gas, thus improving the gas-sensitive property of the materials [28,29].
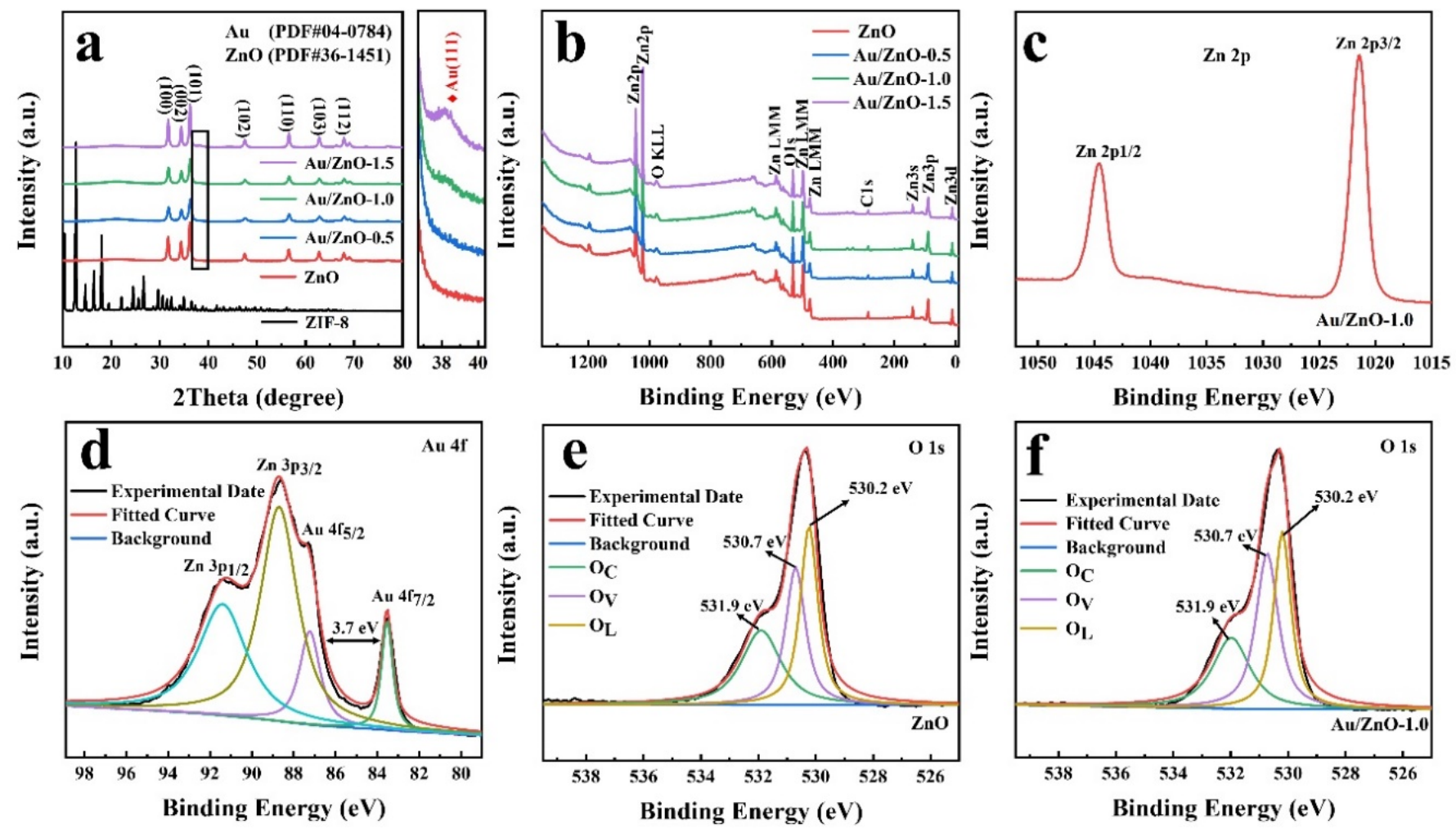

Figure 1. (a) XRD and (b) XPS spectra of ZnO and Au/ZnO samples; (c) XPS spectra of Zn 2p (Au/ZnO-1.0); (d) XPS spectra of $\mathrm{Au} 4 \mathrm{f}(\mathrm{Au} / \mathrm{ZnO}-1.0)$; and (e,f) XPS spectra of O $1 \mathrm{~s}$. 
The ZIF-8 template (Figure $2 b$ ) is converted into $\mathrm{ZnO}$ powder after being calcined above $500{ }^{\circ} \mathrm{C}$. The organic framework of ZIF-8 is decomposed during the firing process to produce a porous structure. The $\mathrm{Zn}$ ions near the surface of the ZIF- 8 frame are directly oxidized to $\mathrm{ZnO}$ in the early stage of firing. In the later stage of firing, the diffusion rate of internal $\mathrm{Zn}$ ions and external oxygen determines the oxidation of internal $\mathrm{Zn}$ ions. Since the rate of outward diffusion of $\mathrm{Zn}$ ions is greater than that of inward diffusion of $\mathrm{O}$ ions, the internal voids are generated by the Kirkendall effect [30-32], as shown in Figure 2c. It can be clearly seen that the structure of ZIF-8 collapsed during the calcination process, and the obtained pure $\mathrm{ZnO}$ mainly presents a particle agglomeration structure with a small amount of dodecahedral structure. The morphologies of $\mathrm{Au} / \mathrm{ZnO}$ samples derived from $\mathrm{Au} / \mathrm{ZIF}-8$ are shown in Figure $2 \mathrm{f}$ and Figure S2. With the loading of $\mathrm{Au}$, the morphologies of $\mathrm{Au} / \mathrm{ZnO}$ materials maintain the original dodecahedron structure of ZIF-8, and no obvious collapse occurred. This may be because Au ions dispersed in the pores of the metal-organic framework, which increases the stability of the ZIF-8 structure during the calcination process. In addition, ZIF-8 is a porous material with high porosity [33]. The 3D Au/ZnO materials prepared with ZIF-8 as a template also have a larger porosity, which is conducive to gas diffusion and increases the gas-sensitive reaction. Lou's team [34] explored the gas-sensing mechanism of the dual effects of surface reaction control and gas diffusion control of $\mathrm{SnO}_{2}$ microspheres. When the reaction temperature is greater than $180{ }^{\circ} \mathrm{C}$ and less than $260^{\circ} \mathrm{C}$, the gas-sensing performance is dually affected by surface reaction control and gas diffusion control. When the temperature is greater than $260^{\circ} \mathrm{C}$, the gas sensitivity is mainly controlled by gas diffusion.

The prepared $\mathrm{Au} / \mathrm{ZnO}$ materials were studied by TEM and HRTEM to gain a deeper understanding of their structural characteristics (Figure 2 and Figure S3). It can be found that the more $\mathrm{Au}$ is loaded, the more Au particles distributed at the edge of $\mathrm{ZnO}$ material from Figure $2 \mathrm{~g}$. This indicates that $\mathrm{Au}$ particles have been successfully modified on the surface of $\mathrm{ZnO}$. The HRTEM image (Figure 2e) of the $\mathrm{ZnO}$ material shows that it has the lattice fringe $(0.247 \mathrm{~nm})$ related to the (101) crystal plane of $\mathrm{ZnO}$. Furthermore, as can be seen from Figure $2 \mathrm{~h}$, the lattice spacing of $\mathrm{Au} / \mathrm{ZnO}$ contains two types: $0.250 \mathrm{~nm}$ and $0.234 \mathrm{~nm}$, which correspond to the (101) crystal plane of $\mathrm{ZnO}$ and the (111) crystal plane of $\mathrm{Au}$, respectively. The results of Figure $2 \mathrm{~g}$, h confirm that the reduced Au ions are uniformly dispersed on the surface of $\mathrm{ZnO}$ and exist in a zero-valence state. The EDS element map is shown in Figure S2g,h. These 3D dodecahedron structures are composed of $\mathrm{Zn}, \mathrm{O}$ and Au, which further proves that $\mathrm{Au}$ elements are evenly distributed in the $\mathrm{ZnO}$ structure.

The $\mathrm{N}_{2}$ adsorption-desorption isotherms (Figure 3) of ZIF-8, pure $\mathrm{ZnO}$ and $\mathrm{Au} / \mathrm{ZnO}$ have been measured to analyze the specific surface area and pore structure of the materials. ZIF-8 has a high specific surface area $\left(1479.70 \mathrm{~m}^{2} \mathrm{~g}^{-1}\right)$, which is used as a template to provide more active sites during the reaction and enhance the gas adsorption capacity. Both $\mathrm{ZnO}$ and $\mathrm{Au} / \mathrm{ZnO}$ show type IV isotherms with hysteresis loops, indicating that there are abundant mesoporous structures in $\mathrm{Au} / \mathrm{ZnO}$ materials. The specific surface areas of $\mathrm{ZnO}, \mathrm{Au} / \mathrm{ZnO}-0.5, \mathrm{Au} / \mathrm{ZnO}-1.0$ and $\mathrm{Au} / \mathrm{ZnO}-1.5$ estimated by the BET model are 16.79, $23.13,22.97$ and $15.65 \mathrm{~m}^{2} \mathrm{~g}^{-1}$, respectively. This result indicates that a proper amount of $\mathrm{Au}$ nanoparticles can increase the specific surface area of the material and the number of surface-active sites effectively. Secondly, the corresponding pore size distributions of $\mathrm{ZnO}$, $\mathrm{Au} / \mathrm{ZnO}-0.5, \mathrm{Au} / \mathrm{ZnO}-1.0$ and $\mathrm{Au} / \mathrm{ZnO}-1.5$ are 5.67, 9.96, 7.14 and $5.37 \mathrm{~nm}$. Larger pore sizes are more conducive to gas diffusion inside the material to improve the gas sensitivity of the material. 

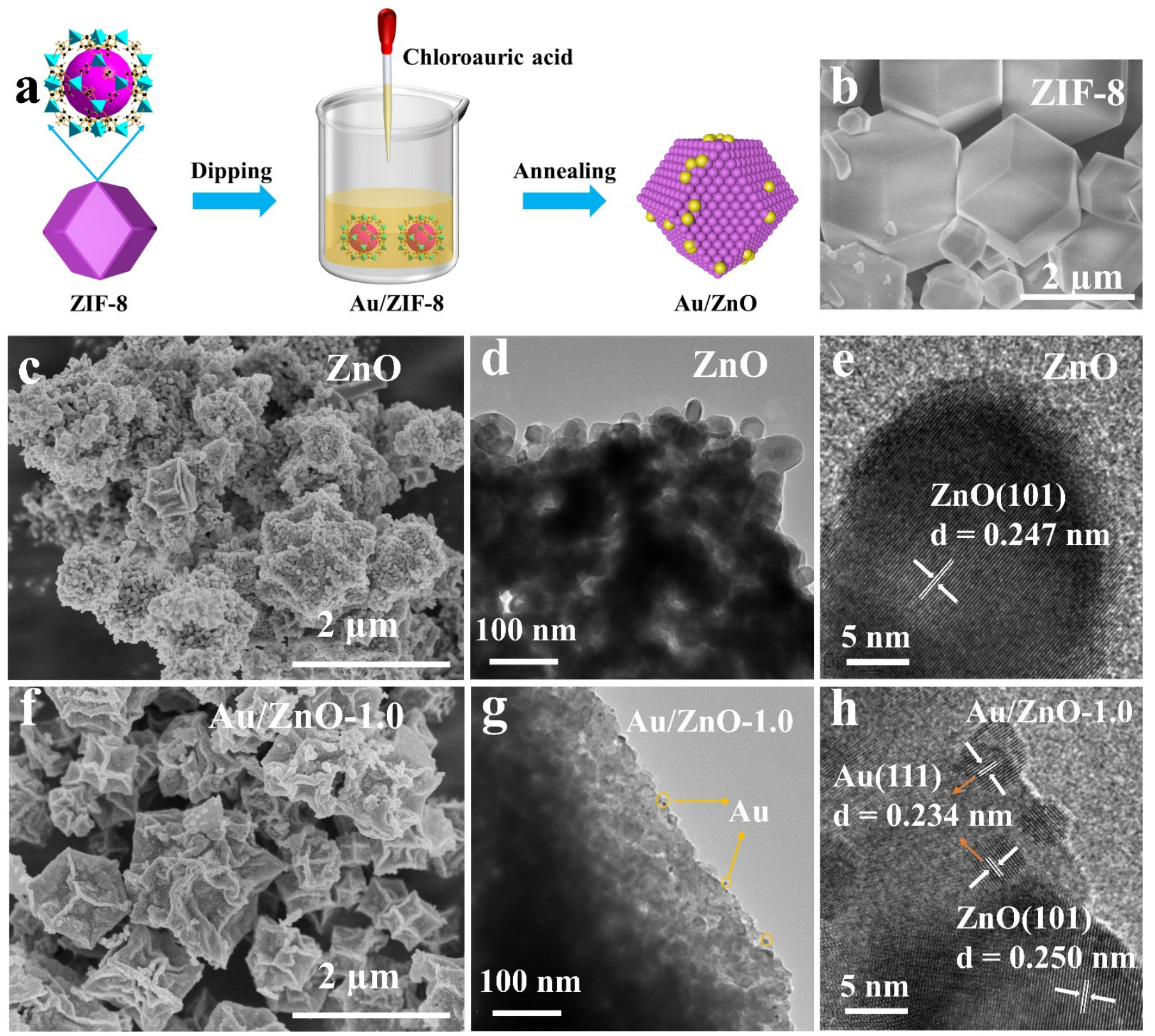

Figure 2. (a) Schematic diagram of preparation of $\mathrm{Au} / \mathrm{ZnO}$ materials; SEM images of (b) ZIF-8, (c) ZnO and (f) Au/ZnO-1.0; TEM and HRTEM images of (d,e) $\mathrm{ZnO}$ and $(\mathbf{g}, \mathbf{h}) \mathrm{Au} / \mathrm{ZnO}-1.0$.

\subsection{Au/ZnO Samples for $\mathrm{C}_{2} \mathrm{H}_{5} \mathrm{OH}$ Sensing Performance Testing and Analysis}

The gas response of a semiconductor sensor usually depends on the operating temperature of the sensor, which determines the surface state, gas adsorption/desorption and chemical reactions on the surface $[3,35]$. In a proper range, the increase in the working temperature is beneficial for the adsorption of oxygen and target gas on the surface of the materials. When the temperature is too high, the rapid dissociation and desorption of the surface gas will be accelerated. Although the resistance of general semiconductors at room temperature exceeds $1000 \mathrm{M} \Omega$ [36], the resistance of the $\mathrm{Au} / \mathrm{ZnO}$ materials prepared in this article at room temperature also exceeds the maximum measurement range (500 M $\Omega$ ). However, the resistance of the materials can be reduced by increasing the operating temperature. In addition, at temperatures below $130{ }^{\circ} \mathrm{C}$, the prepared $\mathrm{Au} / \mathrm{ZnO}$ and $\mathrm{ZnO}$ sensors have poor gas sensitivity. Therefore, the optimal temperature condition was determined by adjusting the operating temperature $\left(130-330^{\circ} \mathrm{C}\right)$ and observing the response of $\mathrm{Au} / \mathrm{ZnO}$ 
and $\mathrm{ZnO}$ sensors to $100 \mathrm{ppm} \mathrm{C}_{2} \mathrm{H}_{5} \mathrm{OH}$. It can be seen that the response of the prepared sensors becomes more intense with the increase of the working temperature. When the temperature reaches a certain value, the gas-sensing response begins to decrease as the temperature continues to increase (Figure 4a). When the response of the sensor is the highest, the corresponding temperature is the best working temperature for gas testing. As shown in Figure $4 b$, the optimal working temperature of the sensors based on $\mathrm{Au} / \mathrm{ZnO}-1.0$ and $\mathrm{Au} / \mathrm{ZnO}-1.5$ is reduced to $250{ }^{\circ} \mathrm{C}$, and the response factor to $100 \mathrm{ppm} \mathrm{C}_{2} \mathrm{H}_{5} \mathrm{OH}$ increased to 37.74 and 26.81, which are almost six times and four times that of $\mathrm{ZnO}$ samples. This result shows that the addition of $\mathrm{Au}$ reduces the working temperature and improves the gas sensitivity. With the increase of the Au load, the gas sensitivity first increases and then decreases, when the load is $1.79 \mathrm{wt}$ \% (data come from ICP) the gas-sensitive response is the largest. Therefore, the optimal load of $\mathrm{Au}$ is $1.79 \mathrm{wt} . \%$, and $250{ }^{\circ} \mathrm{C}$ is the best working temperature for subsequent tests.
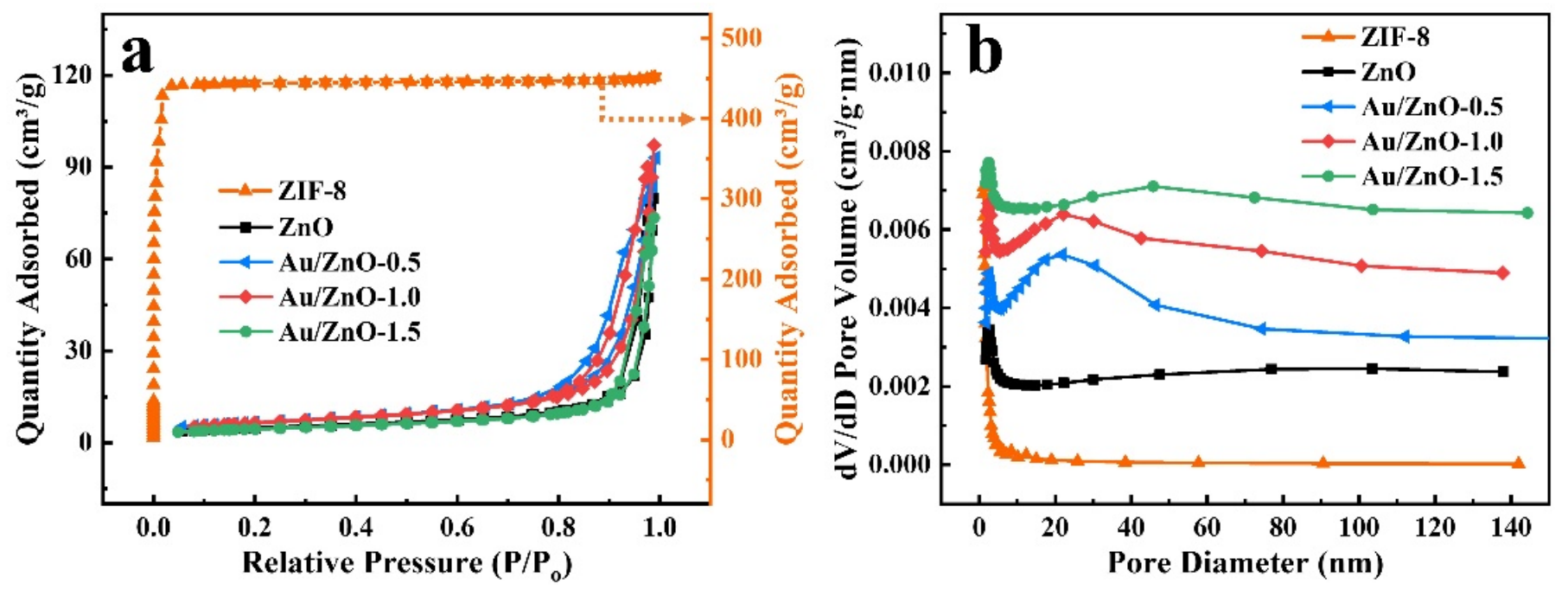

Figure 3. (a) $\mathrm{N}_{2}$ adsorption-desorption isotherms and (b) $\mathrm{BJH}$ pore size distribution of $\mathrm{ZnO}, \mathrm{Au} / \mathrm{ZnO}-0.5, \mathrm{Au} / \mathrm{ZnO}-1.0$ and $\mathrm{Au} / \mathrm{ZnO}-1.5$ samples (each line is shifted upward by $0.0005 \mathrm{~cm}^{3} /(\mathrm{g} \mathrm{nm})$ in $(\mathbf{b})$ ).
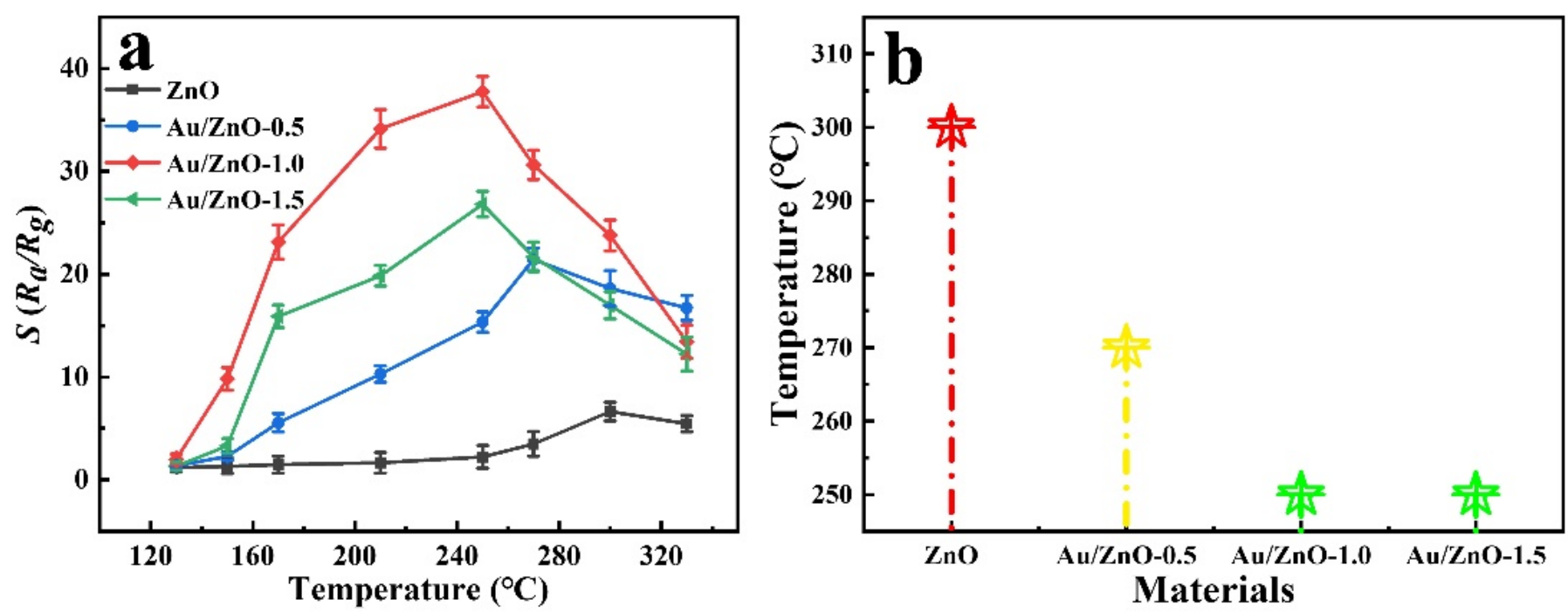

Figure 4. (a) $\mathrm{ZnO}, \mathrm{Au} / \mathrm{ZnO}-0.5, \mathrm{Au} / \mathrm{ZnO}-1.0$ and $\mathrm{Au} / \mathrm{ZnO}-1.5$ working temperature and gas response diagram (100 ppm $\left.\mathrm{C}_{2} \mathrm{H}_{5} \mathrm{OH}\right) ;(\mathbf{b})$ the best working temperature comparison diagram.

The response of the $\mathrm{Au} / \mathrm{ZnO}-1.0$ sensor to $100 \mathrm{ppm} \mathrm{C}_{2} \mathrm{H}_{5} \mathrm{OH}$ is significantly higher than that of the sensor based on the $\mathrm{ZnO}$ in Table 1 . In addition, the best working tem- 
perature of the $\mathrm{Au} / \mathrm{ZnO}-1.0$ sensor is $250{ }^{\circ} \mathrm{C}$, which is lower than most reported best working temperatures. Figure $5 \mathrm{a}, \mathrm{b}$ shows the characteristic curves of different $\mathrm{C}_{2} \mathrm{H}_{5} \mathrm{OH}$ concentrations (1-100 ppm) for pure $\mathrm{ZnO}$ and $\mathrm{Au} / \mathrm{ZnO}-1.0$ at $250{ }^{\circ} \mathrm{C}$. The dynamic curves of other samples are shown in Figure S4. It can be seen clearly that the response of the four sensors increases with the gradual increase of the $\mathrm{C}_{2} \mathrm{H}_{5} \mathrm{OH}$ concentration. Furthermore, at different $\mathrm{C}_{2} \mathrm{H}_{5} \mathrm{OH}$ concentrations, the response of $\mathrm{Au} / \mathrm{ZnO}$ is much higher than that of pure $\mathrm{ZnO}$. This is because the catalysis of $\mathrm{Au}$ increases the oxidation rate of $\mathrm{C}_{2} \mathrm{H}_{5} \mathrm{OH}$ gas. The response of the $\mathrm{Au} / \mathrm{ZnO}-1.0$ sensor is higher than that of other sensors, with a response factor of 37.74 to $100 \mathrm{ppm} \mathrm{C}_{2} \mathrm{H}_{5} \mathrm{OH}$. This is especially true at a low concentration of $1 \mathrm{ppm}$, with a response factor of 1.81 to $\mathrm{C}_{2} \mathrm{H}_{5} \mathrm{OH}$, indicating that the $\mathrm{Au} / \mathrm{ZnO}-1.0$ sensor has a lower detection limit. Figure $5 \mathrm{c}$ is the linear fitting curve of the concentration at $250{ }^{\circ} \mathrm{C}$. It can be seen that the $\mathrm{Au} / \mathrm{ZnO}-1.0$ sensor shows an approximately linear change in the $\mathrm{C}_{2} \mathrm{H}_{5} \mathrm{OH}$ concentration range of 1-100 ppm. The data fitting equation is as follows: $y=0.3748 x+2.7469$, and the correlation coefficient $R^{2}$ is 0.9865 . According to the slope of the linear fitting curve, the sensitivity of $\mathrm{Au} / \mathrm{ZnO}-1.0$ is $0.3748 \mathrm{ppm}^{-1}$ in the range of 1 to $100 \mathrm{ppm}$. A low detection limit is important for providing early warning at the beginning of a leak.

Table 1. The gas sensitivity of $\mathrm{ZnO}$-based sensors for the detection of $\mathrm{C}_{2} \mathrm{H}_{5} \mathrm{OH}$.

\begin{tabular}{|c|c|c|c|c|c|}
\hline Materials & Concentration (ppm) & Temperature $\left({ }^{\circ} \mathrm{C}\right)$ & Response $\left(R_{a} / R_{g}\right)$ & LOD (ppm) & Ref. \\
\hline $\mathrm{CuO} / \mathrm{ZnO}$ nanowires & 100 & 300 & 28 & 1.06 & [37] \\
\hline $\mathrm{Au}, \mathrm{Cl}-\mathrm{ZnO}$ nanoparticles & 100 & 220 & 19.64 & 19.64 & [38] \\
\hline $\mathrm{T}-\mathrm{ZnO} / \mathrm{ZnFe}_{2} \mathrm{O}_{4}$ Tetrapods & 100 & 300 & 13.95 & 1 & [39] \\
\hline $\mathrm{Mg}$ doped $\mathrm{ZnO}$ & 5 & 300 & 80 & 1 & {$[40]$} \\
\hline $\mathrm{Ag} / \mathrm{ZnO}$ nanorods & 100 & 360 & 36.6 & 50 & [41] \\
\hline K-doped $\mathrm{ZnO}$ nanorods & 100 & 300 & 45.2 & 2 & [42] \\
\hline $\mathrm{Ag}-\mathrm{ZnO}$ & 50 & 325 & 32.5 & 50 & [43] \\
\hline $\mathrm{ZnO}$ nanorods & 100 & 300 & 44.9 & 10 & [44] \\
\hline $\mathrm{Au} / \mathrm{ZnO}$ & 100 & 250 & 37.74 & 1 & This work \\
\hline
\end{tabular}

The response $\left(T_{\text {Res }}\right) /$ recovery time $\left(T_{\text {Rec }}\right)$ of the sensor is also one of the important factors in the evaluation of gas performance. The $T_{R e s} / T_{R e c}$ is defined as the time required for the sensor element to reach $90 \%$ response or return to equilibrium when exposed to the target gas or air. A single cycle response of $\mathrm{ZnO}$ and $\mathrm{Au} / \mathrm{ZnO}-1.0$ sensor is shown in Figure $6 \mathrm{a}$. The $T_{\text {Res }} / T_{R e c}$ of $\mathrm{Au} / \mathrm{ZnO}-1.0$ is about $19 / 9 \mathrm{~s}$, which is faster than that of a pure $\mathrm{ZnO}$ sensor (51/13 s). This shows that the Au-supported $\mathrm{ZnO}$ sensor has unique response-recovery characteristics. Good selectivity for a particular gas is a key parameter of gas sensors. In order to evaluate the selectivity of the sensor to $\mathrm{C}_{2} \mathrm{H}_{5} \mathrm{OH}$ at $250{ }^{\circ} \mathrm{C}$, the response of $\mathrm{ZnO}$ and $\mathrm{Au} / \mathrm{ZnO}-1.0$ sensors to $100 \mathrm{ppm} \mathrm{C}_{2} \mathrm{H}_{5} \mathrm{OH}, \mathrm{CH}_{3} \mathrm{OH}$, acetone, toluene, acetaldehyde and ammonia are shown in Figure $6 \mathrm{~b}$. The results show that the response factor of the $\mathrm{Au} / \mathrm{ZnO}-1.0$ to $\mathrm{C}_{2} \mathrm{H}_{5} \mathrm{OH}$ gas is higher than that of other gases, which manifests that the $\mathrm{Au} / \mathrm{ZnO}-1.0$ has high selectivity to $\mathrm{C}_{2} \mathrm{H}_{5} \mathrm{OH}$. In addition, the repeatability of $\mathrm{ZnO}$ and $\mathrm{Au} / \mathrm{ZnO}$ materials to $100 \mathrm{ppm} \mathrm{C}_{2} \mathrm{H}_{5} \mathrm{OH}$ was also measured (Figure $6 \mathrm{c}$ and Figure S5). After five cycles of $\mathrm{C}_{2} \mathrm{H}_{5} \mathrm{OH}$ intake and diffusion, the $\mathrm{ZnO}$ and $\mathrm{Au} / \mathrm{ZnO}$ sensors can still recover the initial resistance, indicating that the sensors have good repeatability. Furthermore, the response factor of the $\mathrm{Au} / \mathrm{ZnO}-1.0$ sensor to $100 \mathrm{ppm} \mathrm{C}_{2} \mathrm{H}_{5} \mathrm{OH}$ has very little downward trend (Figure 6d) after a one-month test period within the error range $(\mathrm{n}=3$, each data point is tested three times) showing their good reversibility and stability. 

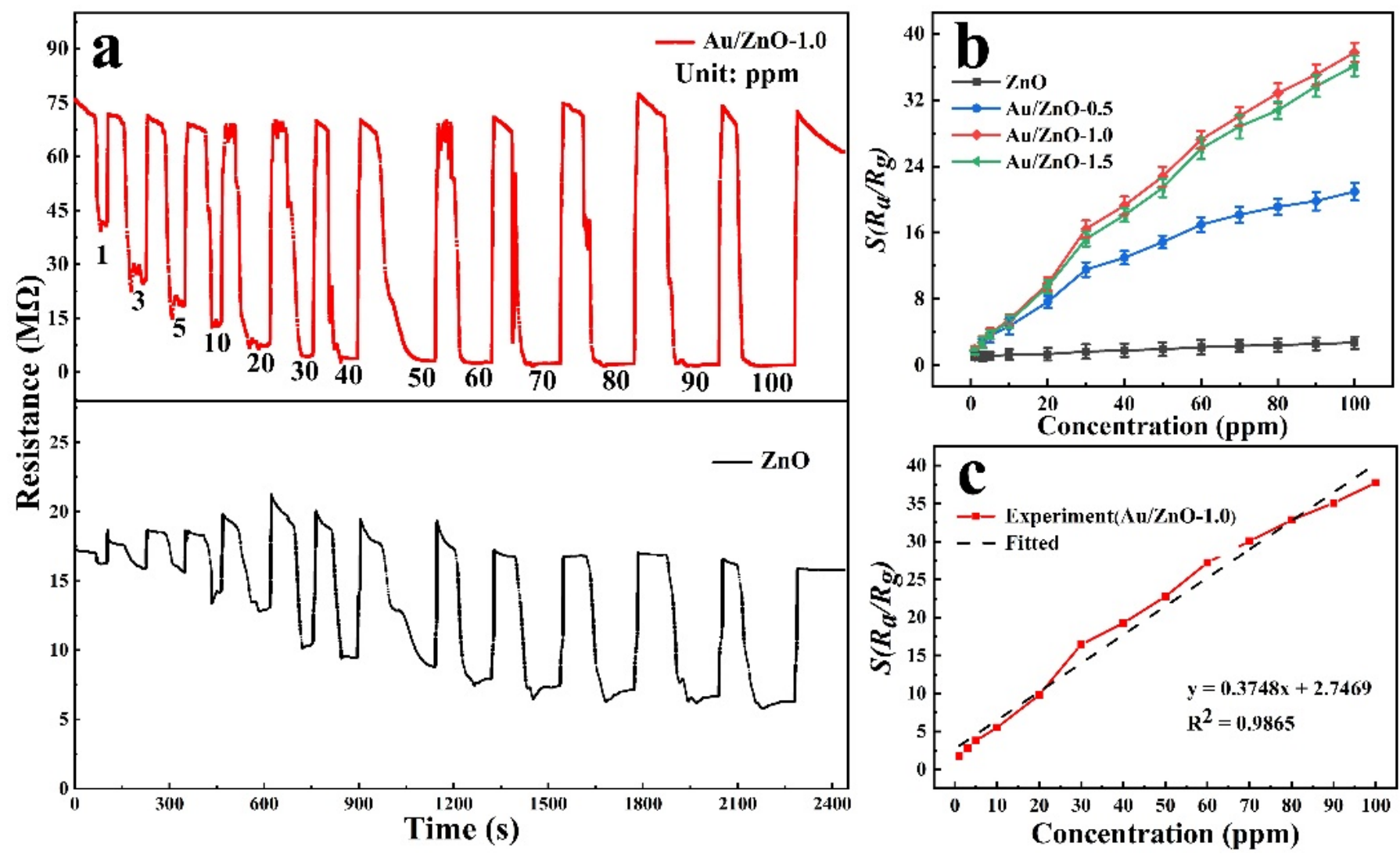

Figure 5. (a) Dynamic response and (b) concentration linearity curve of $\mathrm{ZnO}, \mathrm{Au} / \mathrm{ZnO}-0.5, \mathrm{Au} / \mathrm{ZnO}-1.0$ and $\mathrm{Au} / \mathrm{ZnO}-1.5$ at $250{ }^{\circ} \mathrm{C}\left(\mathrm{C}_{2} \mathrm{H}_{5} \mathrm{OH}: 1-100 \mathrm{ppm}\right) ;(\mathbf{c}) \mathrm{Au} / \mathrm{ZnO}-1.0$ experimental data linear fitting curve.

\subsection{Gas Sensing Mechanism of the Au/ZnO Sensors}

The sensing mechanism of $\mathrm{Au} / \mathrm{ZnO}$ materials can generally be explained by the surface adsorption oxygen model. Because the work function of $\mathrm{Au}(\phi>5.2 \mathrm{eV})$ is higher than that of $\mathrm{ZnO}(4.5 \mathrm{eV})[16,45]$, the electrons in $\mathrm{ZnO}$ move to $\mathrm{Au}$, causing the electron concentration in $\mathrm{Au}$ particles to increase. When the $\mathrm{Au} / \mathrm{ZnO}$ sensors are exposed to air, oxygen will be adsorbed on the $\mathrm{Au} / \mathrm{ZnO}$ surface. Since electrons accumulate in $\mathrm{Au}$ particles, oxygen is more likely to contact $\mathrm{Au}$ particles and capture electrons to form negative oxygen ions $\left(\mathrm{O}_{2}{ }^{-}, \mathrm{O}^{-}, \mathrm{O}^{2-}\right)$, which leads to an increase in the initial resistance. When the reducing gas $\left(\mathrm{C}_{2} \mathrm{H}_{5} \mathrm{OH}\right.$ in our case $)$ is injected into the test chamber, $\mathrm{C}_{2} \mathrm{H}_{5} \mathrm{OH}$ can react with oxygen ions, losing two hydrogen atoms to generate acetaldehyde molecules at first. Then the decomposed acetaldehyde will further react with the adsorbed oxygen ions on the surface to form acetic acid, which is then decomposed into carbon dioxide and water molecules. During this adsorption reaction, the lost electrons of $\mathrm{Au} / \mathrm{ZnO}$ will be released back into the material to reduce the resistance. This paper presents the sensing mechanism diagram of the 3D Au/ $\mathrm{ZnO}$ sensor derived from $\mathrm{ZIF}-8$ (Figure 7). 

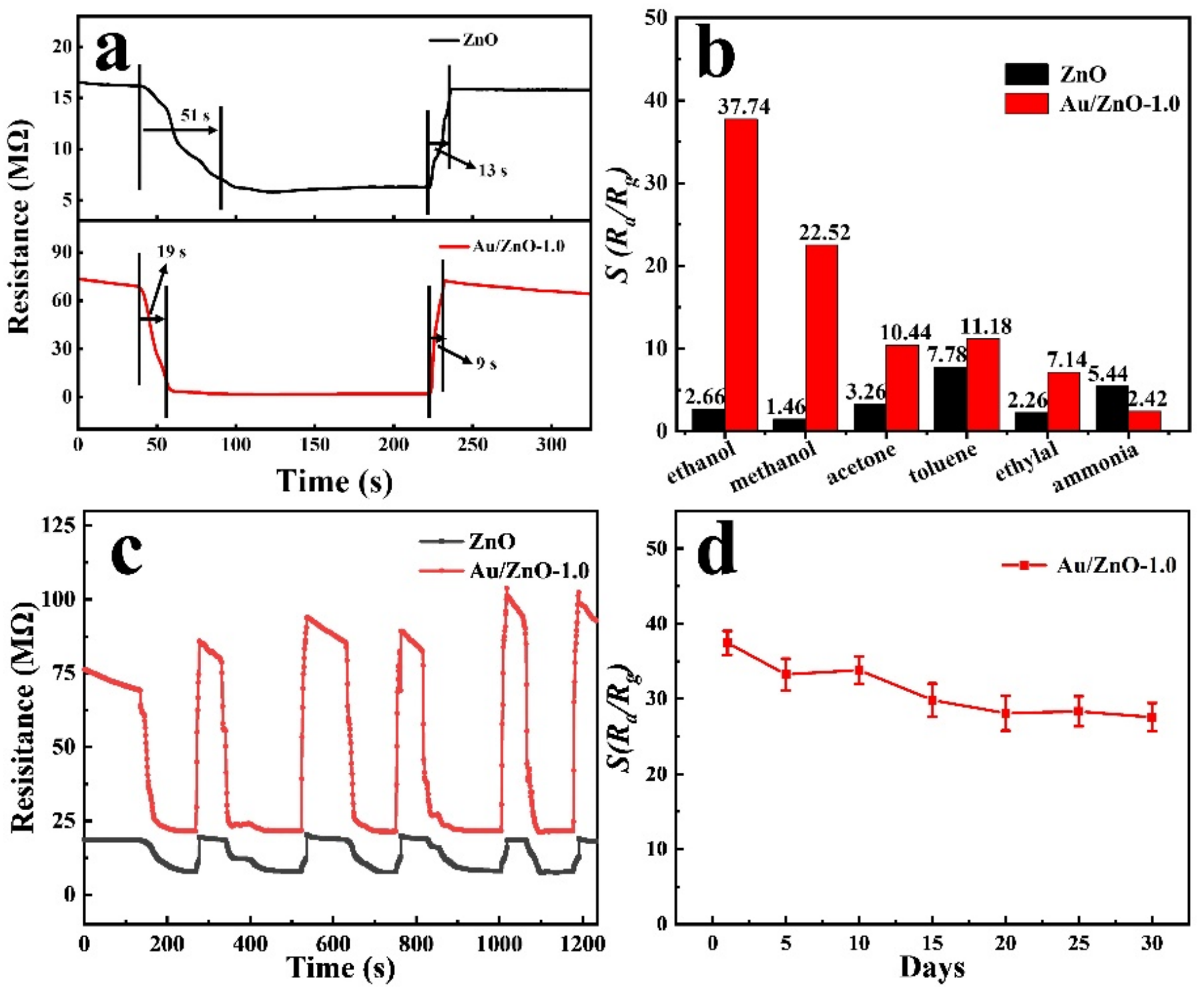

Figure 6. (a) The diagram of $\mathrm{ZnO}$ and $\mathrm{Au} / \mathrm{ZnO}-1.0$ response/recovery time; (b) $\mathrm{ZnO}$ and $\mathrm{Au} / \mathrm{ZnO}-1.0$ gas sensitivity response to other gases (100 ppm); (c) 5-cycle dynamic response-recovery curve; (d) $\mathrm{Au} / \mathrm{ZnO}-1.0$ sensor long-term stability test $\left(\mathrm{C}_{2} \mathrm{H}_{5} \mathrm{OH}: 100 \mathrm{ppm}, \mathrm{n}=3\right.$, temperature: $\left.250{ }^{\circ} \mathrm{C}\right)$.

The improvement of the sensing performance of 3D Au/ZnO derived from $\mathrm{Au} / \mathrm{ZIF}-8$ can be explained by three factors, namely the size effect, the composition design of the sensing material, and the structure design. First, the size effect of Au nanoparticles in the 3D Au/ZnO sensor derived from ZIF-8 should be considered [14]. When the size is reduced to the nanoscale, the catalytic performance of precious metals can be improved effectively [46,47]. In particular, Au nanoparticles can disperse more uniformly, and their size is easier to control under the protection of the ZIF-8 shell layer so that they have a better detection capability for $\mathrm{C}_{2} \mathrm{H}_{5} \mathrm{OH}$. While Au nanoparticles supported on the surface without using the ZIF structure as a template are prone to agglomeration due to their high surface energy, enervating catalytic performance $[48,49]$. Secondly, when introducing precious metals into semiconductor-based resistance sensing devices, the mechanisms of "electronic sensitization" and "chemical sensitization" should be considered [50-52]. Electron sensitization occurs because the electrons in $\mathrm{ZnO}$ transfer to Au when Au nanoparticles are in contact with $\mathrm{ZnO}$, which expands the depletion zone of $\mathrm{ZnO}$. The enlarged depletion region increases the initial barrier, which in turn increases the initial resistance value of $\mathrm{ZnO}$ and enhances the response strength. Chemical sensitization is attributed to 
the catalysis of oxygen separation. The addition of Au nanoparticles helps to reduce the activation energy of oxygen separation into oxygen ions, so more oxygen molecules can be adsorbed on the surface of $\mathrm{ZnO}$ to form oxygen anions, which is also known as the "spillover effect". The generated oxygen ions can react with more $\mathrm{C}_{2} \mathrm{H}_{5} \mathrm{OH}$ gas to enhance the gas response. In addition, the high specific surface area of the 3D dodecahedron structure provides abundant active sites and the high porosity affords more channels for gas diffusion, which lay a good foundation for high-performance sensors.

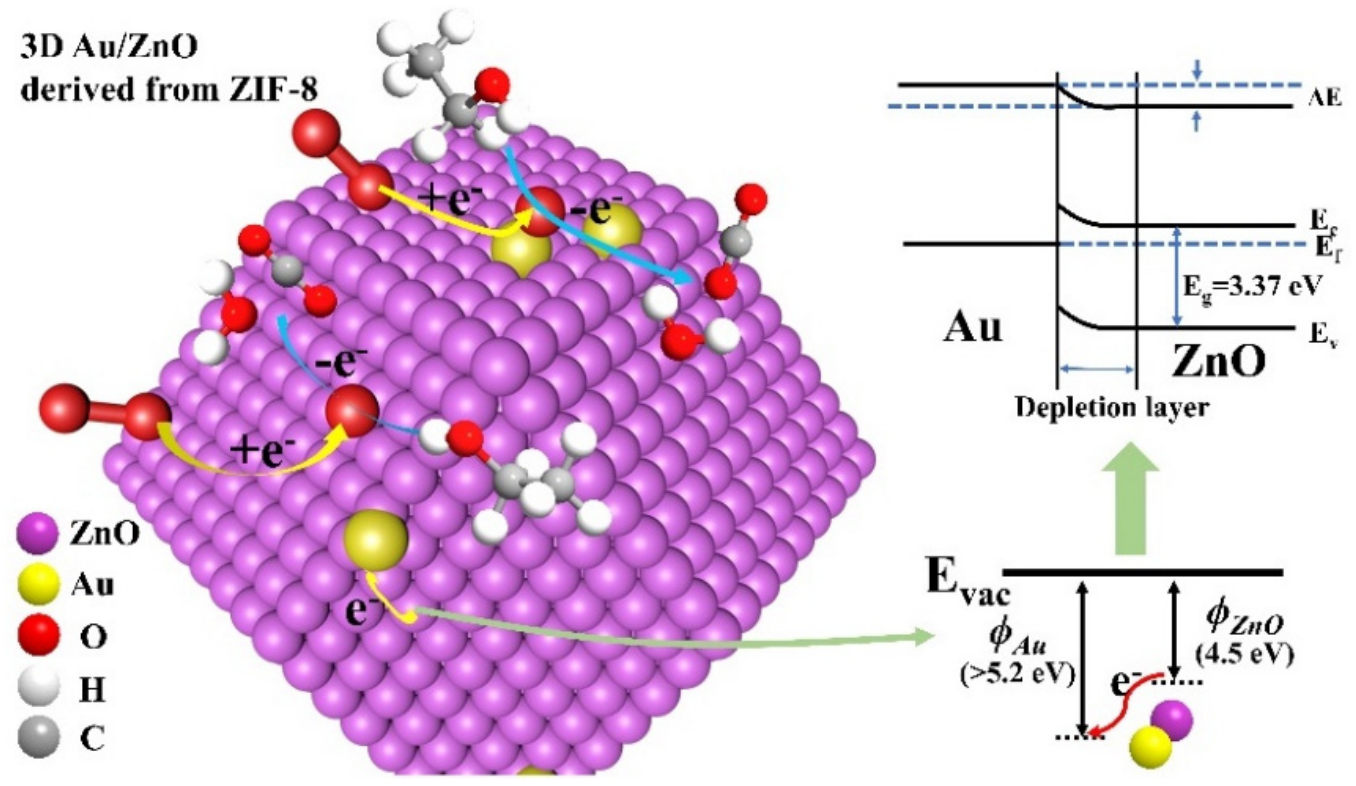

Figure 7. Sensing mechanism in the $\mathrm{Au} / \mathrm{ZnO}$ gas sensor derived from $\mathrm{ZIF}-8$.

\subsection{Adsorption Characteristics of the Au/ZnO Sensors}

DFTs have been extensively utilized to analyze the sensing properties of different materials and great successes have been achieved in various fields [5,53,54]. For example, Monrudee Liangruksa's team applied DFT to study the sensing properties of palladiummodified $\mathrm{ZnO}$ nanofilms to target gases (i.e., hydrogen $\left(\mathrm{H}_{2}\right)$ and $\left.\mathrm{C}_{2} \mathrm{H}_{5} \mathrm{OH}\right)$. The calculation results showed that, compared with bare $\mathrm{ZnO}$, modified $\mathrm{ZnO}$ had a significant promotion effect on the reaction of $\mathrm{H}_{2}$ and $\mathrm{C}_{2} \mathrm{H}_{5} \mathrm{OH}$. The gas sensitivity of the sensor for $\mathrm{H}_{2}$ and $\mathrm{C}_{2} \mathrm{H}_{5} \mathrm{OH}$ detection is mainly attributed to the surface modification and its resulting electron transfer mechanism, DOS, band gap and gas adsorption [55]. Hence, in our work, the first principles analysis of $\mathrm{Au} / \mathrm{ZnO}$ structures based on DFT and linear combinations of atomic orbitals (LCAO) basis set was performed using the Atomistix Toolkit (ATK) to investigate the adsorption properties of the surface of the materials. It is well known that the firstprinciples calculations used by the DFT are usually based on absolute zero. With regard to direct band-gap semiconductors, the random motion of atoms under room temperature can be considered a negligible interference. Therefore, absolute zero is used in the first principles calculation of the $\mathrm{Au} / \mathrm{ZnO}$ structure. Based on XRD and HRTEM analyses, the crystal plane model of $\mathrm{ZnO}$ (101) loaded with Au was constructed. The $\mathrm{Au} / \mathrm{ZnO}$ configuration contains 97 atoms ( $48 \mathrm{Zn}$ atoms, $48 \mathrm{O}$ atoms and $1 \mathrm{Au}$ atom). The $\mathrm{Au} / \mathrm{ZnO}$ structure is periodic in the $\mathrm{x}$ and $\mathrm{y}$ planes, and there is a vacuum layer of $10 \AA$ on the $\mathrm{z}$-axis, in order to avoid imaginary interactions between adjacent atoms. In all calculations, the bottom three layers of the $\mathrm{Au} / \mathrm{ZnO}$ configuration (a total of six atomic layers) remain fixed. The generalized gradient approximation (GGA) of Perdew-Burke-Ernzerh (PBE) represents the exchange-correlation effect of electrons in the DFT calculation. Density mesh cut-off was set to 125 Hartree, and the first Brillouin zones are sampled using $2 \times 3 \times 1$ k-points in the $\mathrm{x}, \mathrm{y}$ and $\mathrm{z}$ directions, respectively. The LBFGS algorithm was used to relax the positions 
of all atoms until the force on each atom was less than $0.05 \mathrm{eV} / \AA$. The geometry of the configuration was optimized (Figure 8).
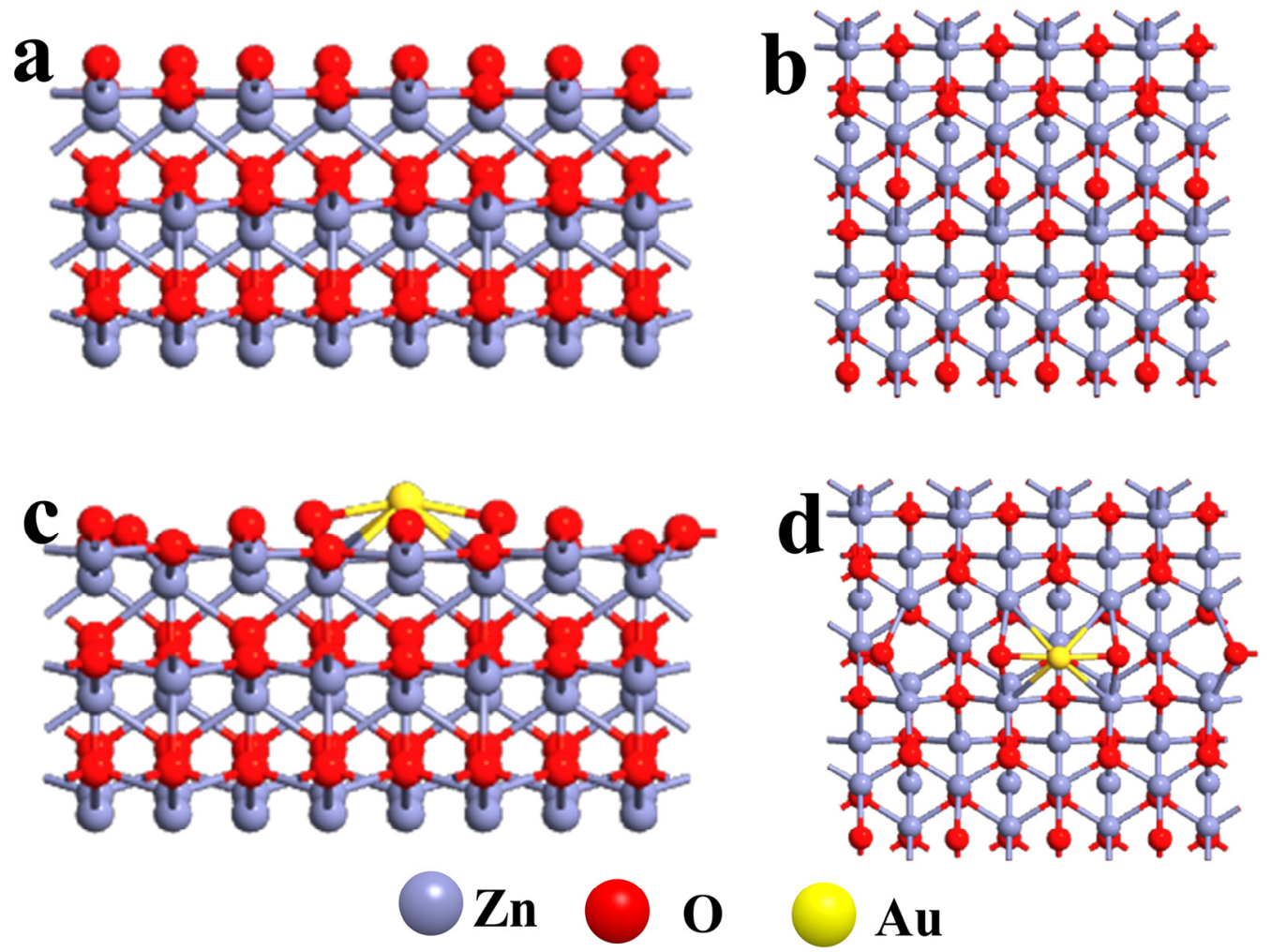

Figure 8. Optimized geometry of $(\mathbf{a}, \mathbf{b}) \mathrm{ZnO}$ and $(\mathbf{c}, \mathbf{d}) \mathrm{Au} / \mathrm{ZnO}$ (side view on the left, top view on the right).

In order to simulate the adsorption characteristics of oxygen molecules on the surface of the material, an oxygen molecule was placed on the optimized $\mathrm{ZnO}$ and $\mathrm{Au} / \mathrm{ZnO}$ configurations, about $3 \AA$ from the surface of the configuration, and the configurations were optimized. By continuously adjusting the position of the oxygen molecules, the geometric configuration with the lowest system energy was obtained. The adsorption energies $\left(E_{a d s}\right)$ of $\mathrm{ZnO}$ and $\mathrm{Au} / \mathrm{ZnO}$ configurations for oxygen were calculated according to the energy of the system. The adsorption energies of the gas molecules on the $\mathrm{ZnO}$ and $\mathrm{Au} / \mathrm{ZnO}$ system are obtained by:

$$
E_{\text {ads }}=E_{(\text {adsorbate/slab })}-\left(E_{\text {slab }}+E_{\text {adsorbate }}\right)
$$

Herein, $E_{(a d s o r b a t e / s l a b)}$ is the total energy of the system interacting with the surface configuration and adsorbate, $E_{(\text {slab })}$ and $E_{(a d s o r b a t e)}$ are the energy of surface configuration and adsorbate respectively. Therefore, negative energy indicates that the adsorption process is exothermic. The larger the absolute value of the calculated adsorption energy is, the stronger the adsorption is [56]. It can be seen from Figure 9 that the adsorption energy of $\mathrm{ZnO}$ for oxygen is $-2.879 \mathrm{eV}$, which is slightly larger than that of $\mathrm{Au} / \mathrm{ZnO}$ for oxygen $(-2.779 \mathrm{eV})$. Moreover, it can be seen that the oxygen molecules are obviously close to the configuration surface, and the distance between the oxygen molecules and the $\mathrm{Au} / \mathrm{ZnO}$ configuration surface is shortened from $2.96 \AA$ to $2.06 \AA$. The elongation of the bond length can be explained by the fact that the oxygen molecules which are adsorbed on the surface of the configuration will extract the surface charge of the $\mathrm{Au} / \mathrm{ZnO}$. Furthermore, the electron concentration in the oxygen molecule increased and the O-O bond weakened. 

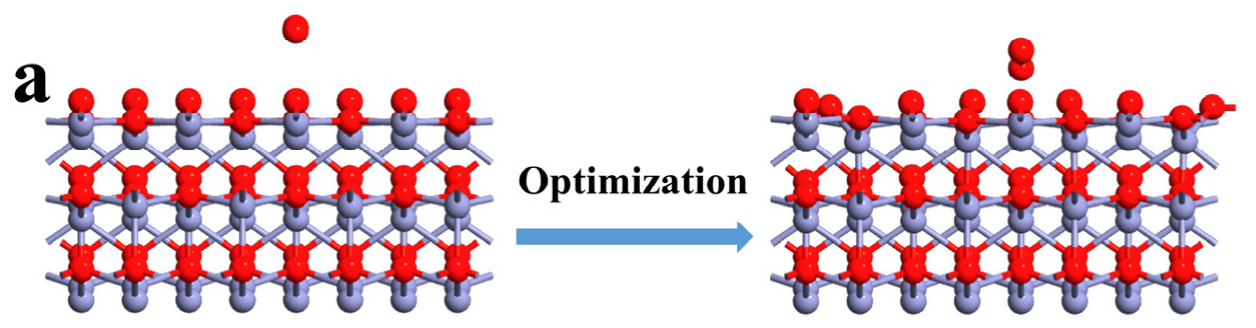

\author{
$\mathrm{ZnO}_{2} \mathrm{O}_{2}$ \\ $E_{\text {ads }}=-2.879 \mathrm{eV}$
}
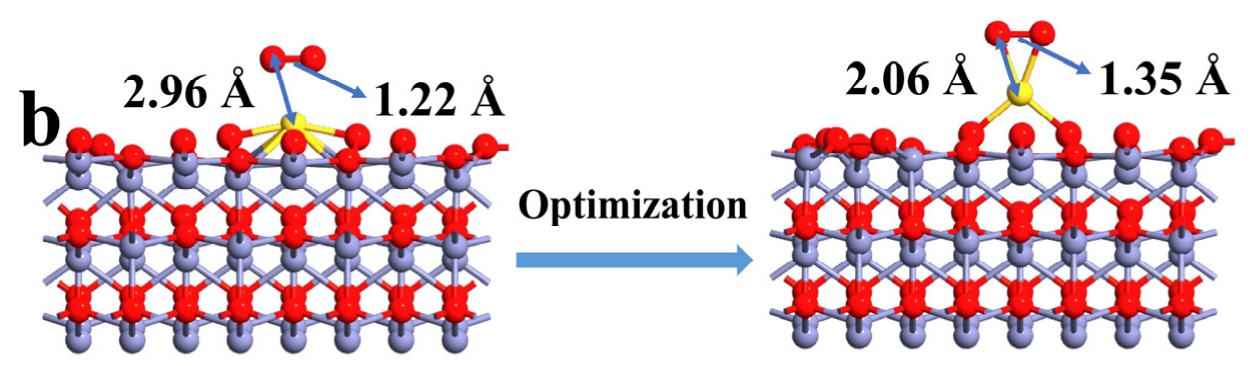

\author{
$\mathrm{Au} / \mathrm{ZnO}-\mathrm{O}_{2}$ \\ $E_{\text {ads }}=-2.779 \mathrm{eV}$
}

\title{
$\mathbf{Z n} \mathbf{0} \bigcirc \mathbf{A u}$
}

Figure 9. The optimized adsorption model of oxygen on the surface of (a) $\mathrm{ZnO}$ and (b) $\mathrm{Au} / \mathrm{ZnO}$.

According to the above simulation analysis, it can be seen that the oxygen molecule has a tendency of cracking during the adsorption process. However, our working temperature was $250{ }^{\circ} \mathrm{C}$ in the actual gas test. High temperature can reduce the activation energy of gas adsorption and provide energy for the cracking of oxygen molecules. Therefore, we simulated the adsorption of a single oxygen atom on the $\mathrm{Au} / \mathrm{ZnO}$ configuration surface (Figure 10a) from experimental considerations. The optimized $\mathrm{Au} / \mathrm{ZnO}-\mathrm{O}$ model was used to explore the interaction between different gases and adsorbed oxygen on the surface, and various gas molecules were placed about $3 \AA$ away from the $\mathrm{Au} / \mathrm{ZnO}$ configuration surface. Then the structure was optimized to obtain the lowest energy configuration of the system. Figure $10 \mathrm{~b}-\mathrm{h}$ is a front view of the structure of $\mathrm{Au} / \mathrm{ZnO}-\mathrm{O}$ adsorbed by different gases. It can be seen from the comparison of adsorption energy that the adsorption capacity of the $\mathrm{Au} / \mathrm{ZnO}$ system to $\mathrm{C}_{2} \mathrm{H}_{5} \mathrm{OH}$ is significantly stronger than that of the $\mathrm{ZnO}$ system. Furthermore, the adsorption intensity of the $\mathrm{Au} / \mathrm{ZnO}$ system to $\mathrm{CH}_{3} \mathrm{OH}$, acetone, toluene, acetaldehyde and ammonia is less than that of the system to $\mathrm{C}_{2} \mathrm{H}_{5} \mathrm{OH}$. Hence, DFT calculations prove that $\mathrm{Au}$-supported $\mathrm{ZnO}$ materials can improve the adsorption of $\mathrm{ZnO}$ to $\mathrm{C}_{2} \mathrm{H}_{5} \mathrm{OH}$, enhancing the gas-sensing response. Moreover, through the comparison of different gas adsorption energies, it proves that $\mathrm{Au} / \mathrm{ZnO}$ materials have good selectivity to $\mathrm{C}_{2} \mathrm{H}_{5} \mathrm{OH}$. 


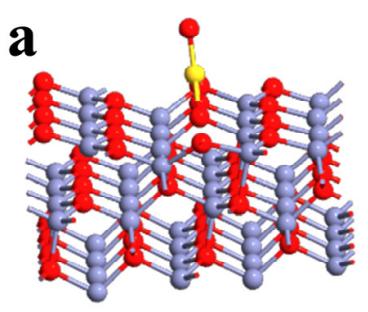

Au/ZnO-O<smiles>CC(C)C(C)C</smiles>

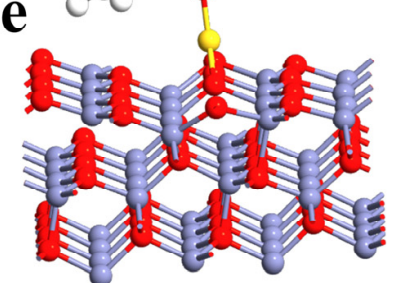

$\mathrm{Au} / \mathrm{ZnO}-\mathrm{O}-\mathrm{CH}_{3} \mathrm{COCH}_{3}$ $\mathbf{E}_{\mathrm{ads}}=-0.277 \mathrm{eV}$
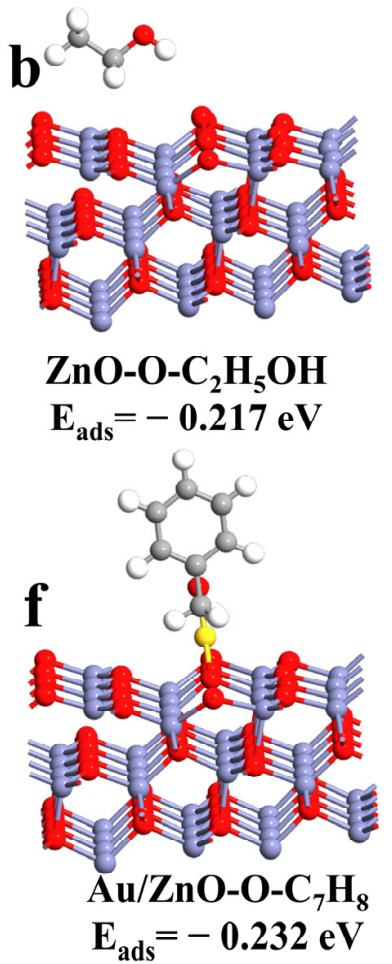

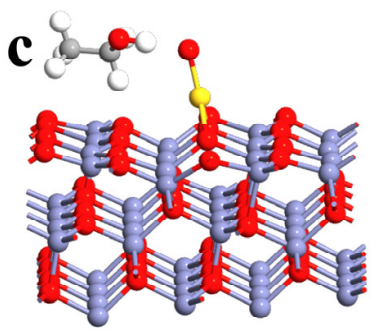

$\mathrm{Au} / \mathrm{ZnO}-\mathrm{O}-\mathrm{C}_{2} \mathrm{H}_{5} \mathrm{OH}$ $E_{\text {ads }}=-1.813 \mathrm{eV}$

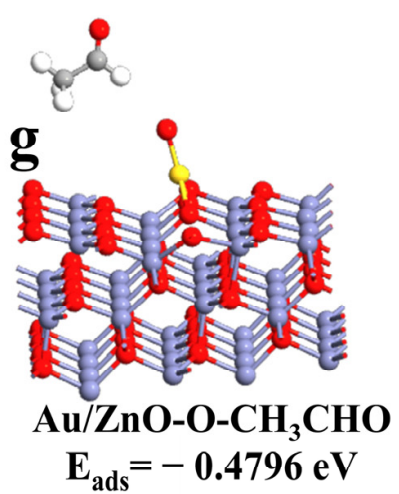

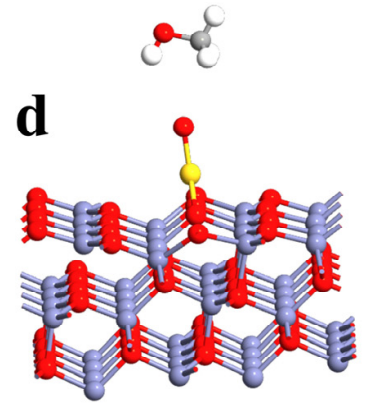
$\mathrm{Au} / \mathrm{ZnO}-\mathrm{O}-\mathrm{CH}_{3} \mathrm{OH}$ $E_{\text {ads }}=-0.307 \mathrm{eV}$

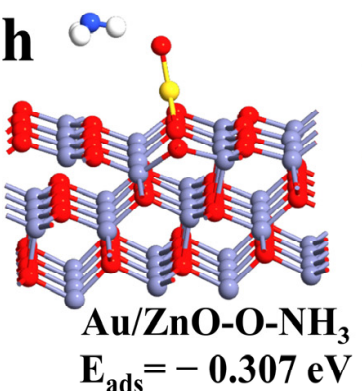

$\mathbf{Z n}$

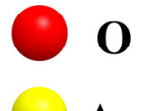

Au

C

H

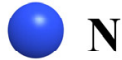

Figure 10. (a) The optimized adsorption model of $\mathrm{Au} / \mathrm{ZnO}-\mathrm{O}$; The optimized adsorption model of different gases on the surface of $\mathrm{ZnO}-\mathrm{O}\left(\mathbf{b}: \mathrm{C}_{2} \mathrm{H}_{5} \mathrm{OH}\right)$ and $\mathrm{Au} / \mathrm{ZnO}-\mathrm{O}\left(\mathbf{c}: \mathrm{C}_{2} \mathrm{H}_{5} \mathrm{OH} ; \mathbf{d}: \mathrm{CH}_{3} \mathrm{OH} ; \mathbf{e}: \mathrm{CH}_{3} \mathrm{COCH}_{3} ; \mathbf{f}: \mathrm{C}_{7} \mathrm{H}_{8} ; \mathbf{g}: \mathrm{CH}_{3} \mathrm{CHO}\right.$ h: $\mathrm{NH}_{3}$ ).

\section{Conclusions}

In conclusion, Au nanoparticles were successfully supported on ZIF-8 derived $\mathrm{ZnO}$. The gas-sensing characteristics of $\mathrm{Au} / \mathrm{ZnO}$ materials were verified by DFT calculation. When the Au load is $1.79 \mathrm{wt} . \%$, the response of the obtained sensor $(\mathrm{Au} / \mathrm{ZnO}-1.0)$ to $\mathrm{C}_{2} \mathrm{H}_{5} \mathrm{OH}$ is improved significantly. The response of the $\mathrm{Au} / \mathrm{ZnO}-1.0$ sensor to $100 \mathrm{ppm}$ $\mathrm{C}_{2} \mathrm{H}_{5} \mathrm{OH}$ at $250^{\circ} \mathrm{C}$ is 37.74 , which is about 6 times that of pure $\mathrm{ZnO}$ material. The sensor also has a faster response/recovery time, about 19/9 s. In addition, the gas sensor has good selectivity, repeatability and stability to $\mathrm{C}_{2} \mathrm{H}_{5} \mathrm{OH}$. The DFT calculation shows that the adsorption energies of $\mathrm{ZnO}$ and $\mathrm{Au} / \mathrm{ZnO}$ for oxygen are $-2.879 \mathrm{eV}$ and $-2.779 \mathrm{eV}$, and the $\mathrm{O}-\mathrm{O}$ bond has been elongated. The adsorption energies of adsorbed oxygen on the $\mathrm{ZnO}$ and $\mathrm{Au} / \mathrm{ZnO}$ surface to $\mathrm{C}_{2} \mathrm{H}_{5} \mathrm{OH}$ are -0.217 and $-1.813 \mathrm{eV}$, and the adsorption strength of $\mathrm{Au} / \mathrm{ZnO}$ to $\mathrm{C}_{2} \mathrm{H}_{5} \mathrm{OH}$ is significantly higher than that of several gases. In summary, the loading of $\mathrm{Au}$ further enhances the gas adsorption on the surface of $\mathrm{ZnO}$ and reduces the activation energy for gas adsorption and reaction. Simultaneously, the size of $\mathrm{Au}$ nanoparticles can be adjusted to a certain extent under the protection of the ZIF-8 shell layer, and they are evenly dispersed on the three-dimensional $\mathrm{ZnO}$ framework, thereby effectively enhancing the sensing performance of $\mathrm{C}_{2} \mathrm{H}_{5} \mathrm{OH}$ gas.

Supplementary Materials: The following are available online at https:/ /www.mdpi.com/article/10 .3390/s21134352/s1, Figure S1: SEM images of (a) Au/ZnO-0.5, (b) Au/ZnO-1.5. Figure S2: (a,b) TEM images of $\mathrm{Au} / \mathrm{ZnO}-0.5$ and $\mathrm{Au} / \mathrm{ZnO}-1.5$, (c,d) Mapping spectrum of Au/ZnO-1.0. Figure S3: Dynamic response graph of (a) $\mathrm{Au} / \mathrm{ZnO}-1.5$ and (b) $\mathrm{Au} / \mathrm{ZnO}-0.5$ samples to $\mathrm{C}_{2} \mathrm{H}_{5} \mathrm{OH}$ (1-100 ppm). Figure S4: 5-cycle dynamic response-recovery curve of (a) $\mathrm{Au} / \mathrm{ZnO}-0.5$ and (b) $\mathrm{Au} / \mathrm{ZnO}-1.5$ samples to $\mathrm{C}_{2} \mathrm{H}_{5} \mathrm{OH}$ (100 ppm). Table S1: Au element content in $\mathrm{Au} / \mathrm{ZnO}$ samples (ICP). 
Author Contributions: Conceptualization, Y.K. and F.Y.; methodology, Y.K.; software, Y.K.; validation, Y.K., W.W. and L.Z.; formal analysis, Y.K.; investigation, Y.K.; resources, F.Y.; data curation, Y.K.; writing—original draft preparation, Y.K.; writing—review and editing, F.Y. and L.Z.; visualization, Y.K. and W.W.; supervision, F.Y.; project administration, F.Y.; funding acquisition, F.Y. All authors have read and agreed to the published version of the manuscript.

Funding: This work was supported by Science and Technology Innovation Talents Program of Bingtuan (No. 2019CB025).

Informed Consent Statement: Informed consent was obtained from all subjects involved in the study.

Acknowledgments: The authors acknowledge the financial support by the Science and Technology Innovation Talents Program of Bingtuan and Shihezi University's research grant.

Conflicts of Interest: The authors declare no conflict of interest.

\section{References}

1. Li, B.; Liu, J.; Liu, Q.; Chen, R.; Zhang, H.; Yu, J.; Song, D.; Li, J.; Zhang, M.; Wang, J. Core-shell structure of ZnO/Co ${ }_{3} \mathrm{O}_{4}$ composites derived from bimetallic-organic frameworks with superior sensing performance for ethanol gas. Appl. Surf. Sci. 2019, 475, 700-709. [CrossRef]

2. Cao, P.; Yang, Z.; Navale, S.T.; Han, S.; Liu, X.; Liu, W.; Lu, Y.; Stadler, F.J.; Zhu, D. Ethanol sensing behavior of Pd-nanoparticles decorated ZnO-nanorod based chemiresistive gas sensors. Sens. Actuators B 2019, 298, 126850. [CrossRef]

3. Zhang, K.; Qin, S.; Tang, P.; Feng, Y.; Li, D. Ultra-sensitive ethanol gas sensors based on nanosheet-assembled hierarchical $\mathrm{ZnO}-\mathrm{In}_{2} \mathrm{O}_{3}$ heterostructures. J. Hazard. Mater. 2020, 391, 122191. [CrossRef]

4. Kang, Y.; Yu, F.; Zhang, L.; Wang, W.; Chen, L.; Li, Y. Review of ZnO-based nanomaterials in gas sensors. Solid State Ion. 2021, 360, 115544. [CrossRef]

5. Yan, Z.; Tao, C.; Bai, Y.; Liu, S. Adsorption of nitrogen based gas molecules on noble metal functionalized carbon nitride nanosheets: A theoretical investigation. Comput. Theor. Chem. 2021, 1194, 112950. [CrossRef]

6. Chauhan, P.S.; Mishra, A.; Bhatt, G.; Bhattacharya, S. Enhanced He gas detection by $\mathrm{V}_{2} \mathrm{O}_{5}-\mathrm{noble}$ metal (Au, Ag, and Pd) nanocomposite with temperature dependent n- to p-type transition. Mater. Sci. Semicond. Process. 2021, 123, 105528. [CrossRef]

7. Zhang, S.; Liu, Z.; Zhang, L.; Chen, J.; Zhou, Q.; Zhang, H.; Nie, L.; Dong, Z.; Zhang, Z.A.; Wang, Z.; et al. Construction of a low-temperature, highly sensitive $\mathrm{H}_{2} \mathrm{~S}$ sensor based on surfaces and interfaces reaction triggered by Au-doped hierarchical structured composites. Chem. Phys. Lett. 2021, 763, 138188. [CrossRef]

8. Cheng, J.; Hu, D.; Yao, A.; Gao, Y.; Asadi, H. A computational study on the Pd-decorated ZnO nanocluster for $\mathrm{H}_{2}$ gas sensing: A comparison with experimental results. Phys. E Low-Dimens. Syst. Nanostruct. 2020, 124, 114237. [CrossRef]

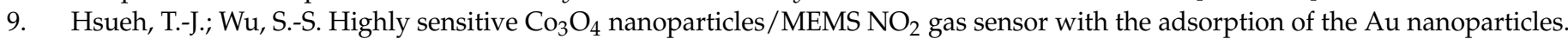
Sens. Actuators B Chem. 2021, 329, 129201. [CrossRef]

10. Cui, W.; Kang, X.; Zhang, X.; Zheng, Z.; Cui, X. Facile synthesis of porous cubic microstructure of $\mathrm{Co}_{3} \mathrm{O}_{4}$ from ZIF-67 pyrolysis and its Au doped structure for enhanced acetone gas-sensing. Phys. E Low-Dimens. Syst. Nanostruct. 2019, 113, 165-171. [CrossRef]

11. Kohl, D. The role of noble metals in the chemistry of solid-state gas sensors. Sens. Actuators B Chem. 1990, 1, 158-165. [CrossRef]

12. Koo, W.T.; Qiao, S.; Ogata, A.F.; Jha, G.; Jang, J.S.; Chen, V.T.; Kim, I.D.; Penner, R.M. Accelerating palladium nanowire $\mathrm{H}_{2}$ sensors using engineered nanofiltration. ACS Nano 2017, 11, 9276-9285. [CrossRef] [PubMed]

13. Hsueh, T.-J.; Peng, C.-H.; Chen, W.-S. A transparent ZnO nanowire MEMS gas sensor prepared by an ITO micro-heater. Sens. Actuators B Chem. 2020, 304, 127319. [CrossRef]

14. Zhou, X.; Lin, X.; Yang, S.; Zhu, S.; Chen, X.; Dong, B.; Bai, X.; Wen, X.; Geyu, L.; Song, H. Highly dispersed Metal-OrganicFramework-Derived $\mathrm{Pt}$ nanoparticles on three-dimensional macroporous $\mathrm{ZnO}$ for trace-level $\mathrm{H}_{2} \mathrm{~S}$ sensing. Sens. Actuators $B$ Chem. 2020, 309, 127802. [CrossRef]

15. Wang, J.; Han, G.; Wang, L.; Du, L.; Chen, G.; Gao, Y.; Ma, Y.; Du, C.; Cheng, X.; Zuo, P.; et al. ZIF-8 with ferrocene encapsulated: A promising precursor to single-atom Fe embedded nitrogen-doped carbon as highly efficient catalyst for oxygen electroreduction. Small 2018, 14, 1704282. [CrossRef] [PubMed]

16. Zhang, B.; Wang, Y.; Meng, X.; Zhang, Z.; Mu, S. High response methane sensor based on Au-modified hierarchical porous nanosheets-assembled ZnO microspheres. Mater. Chem. Phys. 2020, 250, 123027. [CrossRef]

17. Zhang, N.; Yan, L.; Lu, Y.; Fan, Y.; Guo, S.; Adimi, S.; Liu, D.; Ruan, S. Metal-organic frameworks-derived hierarchical ZnO structures as efficient sensing materials for formaldehyde detection. Chin. Chem. Lett. 2020, 31, 2071-2076. [CrossRef]

18. Zhang, L.; Dong, R.; Zhu, Z.; Wang, S. Au nanoparticles decorated ZnS hollow spheres for highly improved gas sensor performances. Sens. Actuators B Chem. 2017, 245, 112-121. [CrossRef]

19. Zhang, J.; Liu, X.; Wang, L.; Yang, T.; Guo, X.; Wu, S.; Zhang, S.; Wang, S. A simple one-pot strategy for the synthesis of ternary reduced graphite oxide $/ \mathrm{SnO}_{2} / \mathrm{Au}$ hybrid nanomaterials. Carbon 2011, 49, 3538-3543. [CrossRef]

20. Zhang, J.; Liu, X.; Wu, S.; Xu, M.; Guo, X.; Wang, S. Au nanoparticle-decorated porous $\mathrm{SnO}_{2}$ hollow spheres: A new model for a chemical sensor. J. Mater. Chem. 2010, 20, 6453-6459. [CrossRef] 
21. Yu, S.; Zhang, H.; Chen, C.; Lin, C. Investigation of humidity sensor based on Au modified ZnO nanosheets via hydrothermal method and first principle. Sens. Actuators B Chem. 2019, 287, 526-534. [CrossRef]

22. Li, H.; Chu, S.; Ma, Q.; Fang, Y.; Wang, J.; Che, Q.; Wang, G.; Yang, P. Novel construction of morphology-tunable C$\mathrm{N} / \mathrm{SnO}_{2} / \mathrm{ZnO} / \mathrm{Au}$ microspheres with ultrasensitivity and high selectivity for triethylamine under various temperature detections. ACS Appl. Mater. Interfaces 2019, 11, 8601-8611. [CrossRef]

23. Yang, T.H.; Huang, L.D.; Harn, Y.W.; Lin, C.C.; Chang, J.K.; Wu, C.I.; Wu, J.M. High density unaggregated Au nanoparticles on $\mathrm{ZnO}$ nanorod arrays function as efficient and recyclable photocatalysts for environmental purification. Small 2013, 9, 3169-3182. [CrossRef]

24. Kumaravel, V.; Mathew, S.; Bartlett, J.; Pillai, S.C. Photocatalytic hydrogen production using metal doped TiO 2 : A review of recent advances. Appl. Catal. B 2018, 244, 1021-1064. [CrossRef]

25. Shingange, K.; Tshabalala, Z.P.; Ntwaeaborwa, O.M.; Motaung, D.E.; Mhlongo, G.H. Highly selective $\mathrm{NH}_{3}$ gas sensor based on Au loaded $\mathrm{ZnO}$ nanostructures prepared using microwave-assisted method. J. Colloid Interface Sci. 2016, 479, 127-138. [CrossRef] [PubMed]

26. Xing, R.; Li, Q.; Lei, X.; Jian, S.; Song, H. Au modified three-dimensional $\mathrm{In}_{2} \mathrm{O}_{3}$ inverse opals: Synthesis and improved performance for acetone sensing toward diagnosis of diabetes. Nanoscale 2015, 7, 13051-13060. [CrossRef] [PubMed]

27. Yang, S.; Sun, J.; Xu, L.; Zhou, Q.; Chen, X.; Zhu, S.; Dong, B.; Lu, G.; Song, H. Au@ZnO functionalized three-dimensional macroporous $\mathrm{WO}_{3}$ : A application of selective $\mathrm{H}_{2} \mathrm{~S}$ gas sensor for exhaled breath biomarker detection. Sens. Actuators $B$ 2020, 324, 128725. [CrossRef]

28. Zhou, X.; Wang, A.; Wang, Y.; Bian, L.; Yang, Z.; Bian, Y.; Gong, Y.; Wu, X.; Han, N.; Chen, Y. Crystal defect dependent gas sensing mechanism of the single ZnO nanowire sensors. ACS Sens. 2018, 3, 2385-2393. [CrossRef] [PubMed]

29. Wei, W.; Zhao, J.; Shi, S.; Lin, H.; Mao, Z.; Zhang, F.; Qu, F. Boosting ppb-level triethylamine sensing of ZnO: Adjusting proportions of electron donor defects. J. Mater. Chem. C 2020, 8, 6734-6742. [CrossRef]

30. Zhang, R.; Zhou, T.; Wang, L.; Zhang, T. Metal-organic frameworks-derived hierarchical $\mathrm{Co}_{3} \mathrm{O}_{4}$ structures as efficient sensing materials for acetone detection. ACS Appl. Mater. Interfaces 2018, 10, 9765-9773. [CrossRef]

31. Lu, H.-B.; Liao, L.; Li, H.; Wang, D.-F.; Tian, Y.; Li, J.-C.; Fu, Q.; Zhu, B.-P.; Wu, Y. Hollow MgO nanotube arrays by using ZnO nanorods as templates. Eur. J. Inorg. Chem. 2008, 2008, 2727-2732. [CrossRef]

32. Wang, W.; Dahl, M.; Yin, Y. Hollow nanocrystals through the nanoscale kirkendall effect. Chem. Mater. 2012, 25, 1179-1189. [CrossRef]

33. Li, W.; Wu, X.; Liu, H.; Chen, J.; Tang, W.; Chen, Y. Hierarchical hollow ZnO cubes constructed using self-sacrificial ZIF-8 frameworks and their enhanced benzene gas-sensing properties. New J. Chem. 2015, 39, 7060-7065. [CrossRef]

34. Wang, X.; Wang, Y.; Tian, F.; Liang, H.; Wang, K.; Zhao, X.; Lu, Z.; Jiang, K.; Yang, L.; Lou, X. From the surface reaction control to gas-diffusion control: The synthesis of hierarchical porous $\mathrm{SnO}_{2}$ microspheres and their gas-sensing mechanism. J. Phys. Chem. C 2015, 119, 15963-15976. [CrossRef]

35. Xiong, H.; Fu, J.; Li, J.; Ali, R.; Wang, H.; Liu, Y.; Su, H.; Li, Y.; Lau, W.-M.; Mahmood, N.; et al. Strain-regulated sensing properties of $\alpha$-Fe2O3 nano-cylinders with atomic carbon layers for ethanol detection. J. Mater. Sci. Technol. 2021, 68, 132-139. [CrossRef]

36. Yu, Z.; Gao, J.; Xu, L.; Liu, T.; Liu, Y.; Wang, X.; Suo, H.; Zhao, C. Fabrication of lettuce-like ZnO gas sensor with enhanced $\mathrm{H}_{2} \mathrm{~S}$ gas sensitivity. Crystals 2020, 10, 145. [CrossRef]

37. Zhao, S.; Shen, Y.; Hao, F.; Kang, C.; Meng, F. P-n junctions based on CuO-decorated ZnO nanowires for ethanol sensing application. Appl. Surf. Sci. 2021, 538, 148140. [CrossRef]

38. Zhang, Y.; Zhao, X.; Hao, W.; Sun, L.; Cao, E. Ethanol sensing characteristics of Au and Cl-comodified ZnO nanoparticles. Mater. Lett. 2020, 279, 128505. [CrossRef]

39. Mei, H.; Zhou, S.; Lu, M.; Cheng, L. Tetrapod-like $\mathrm{ZnO} / \mathrm{ZnFe}_{2} \mathrm{O}_{4}$ based heterostructure for enhanced ethanol detection. J. Alloys Compd. 2020, 840, 155583. [CrossRef]

40. Jaballah, S.; Benamara, M.; Dahman, H.; Ly, A.; Mir, L. Effect of Mg-doping ZnO nanoparticles on detection of low ethanol concentrations. Mater. Chem. Phys. 2020, 255, 123643. [CrossRef]

41. Wei, Y.; Wang, X.; Yi, G.; Zhou, L.; Cao, J.; Sun, G.; Chen, Z.; Bala, H.; Zhang, Z. Hydrothermal synthesis of Ag modified ZnO nanorods and their enhanced ethanol-sensing properties. Mater. Sci. Semicond. Process. 2017, 75, 327-333. [CrossRef]

42. Saaedi, A.; Yousefi, R. Improvement of gas-sensing performance of ZnO nanorods by group-I elements doping. J. Appl. Phys. 2017, 122, 224505. [CrossRef]

43. Yousefi, H.R.; Hashemi, B.; Mirzaei, A.; Roshan, H.; Sheikhi, M.H. Effect of Ag on the ZnO nanoparticles properties as an ethanol vapor sensor. Mater. Sci. Semicond. Process. 2020, 117, 105172. [CrossRef]

44. Zhao, S.; Shen, Y.; Yan, X.; Zhou, P.; Yin, Y.; Lu, R.; Han, C.; Cui, B.; Wei, D. Complex-surfactant-assisted hydrothermal synthesis of one-dimensional ZnO nanorods for high-performance ethanol gas sensor. Sens. Actuators B Chem. 2019, 286, 501-511. [CrossRef]

45. Sundaram, K.B.; Khan, A. Work function determination of zinc oxide films. J. Vac. Sci. Technol. 1997, 15, 428-430. [CrossRef]

46. Lee, J.-S.; Katoch, A.; Kim, J.-H.; Kim, S.S. Effect of Au nanoparticle size on the gas-sensing performance of p-CuO nanowires. Sens. Actuators B Chem. 2016, 222, 307-314. [CrossRef]

47. Zhang, Y.; Xu, J.; Xu, P.; Zhu, Y.; Chen, X.; Yu, W. Decoration of ZnO nanowires with Pt nanoparticles and their improved gas sensing and photocatalytic performance. Nanotechnology 2010, 21, 285501. [CrossRef] 
48. He, L.; Liu, Y.; Liu, J.; Xiong, Y.; Zheng, J.; Liu, Y.; Tang, Z. Core-shell noble-metal@metal-organic-framework nanoparticles with highly selective sensing property. Angew. Chem. 2013, 125, 3829-3833. [CrossRef]

49. Fu, F.; Wang, C.; Wang, Q.; Martinez-Villacorta, A.M.; Escobar, A.; Chong, H.; Wang, X.; Moya, S.; Salmon, L.; Fouquet, E. Highly selective and sharp volcano-type synergistic $\mathrm{Ni}_{2}$ Pt@ZIF-8-catalyzed hydrogen evolution from ammonia borane hydrolysis. J. Am. Chem. Soc. 2018, 140, 10034-10042. [CrossRef]

50. Lee, J.; Jung, Y.; Sung, S.-H.; Lee, G.; Kim, J.; Seong, J.; Shim, Y.-S.; Jun, S.C.; Jeon, S. High-performance gas sensor array for indoor air quality monitoring: The role of Au nanoparticles on $\mathrm{WO}_{3}, \mathrm{SnO}_{2}$, and NiO-based gas sensors. J. Mater. Chem. A 2021, 9 , 1159-1167. [CrossRef]

51. Rai, P.; Majhi, S.M.; Yu, Y.-T.; Lee, J.-H. Noble metal@metal oxide semiconductor core@shell nano-architectures as a new platform for gas sensor applications. RSC Adv. 2015, 5, 76229-76248. [CrossRef]

52. Velmathi, G.; Mohan, S.; Henry, R. Analysis of factors for improving functionality of tin oxide gas sensor. IETE Tech. Rev. 2015, 33, 122-129. [CrossRef]

53. Li, J.-H.; $\mathrm{Wu}, \mathrm{J} . ; \mathrm{Yu}, \mathrm{Y} .-\mathrm{X}$. DFT exploration of sensor performances of two-dimensional $\mathrm{WO}_{3}$ to ten small gases in terms of work function and band gap changes and I-V responses. Appl. Surf. Sci. 2021, 546, 149104. [CrossRef]

54. Fu, J.; Ali, R.; Mu, C.; Liu, Y.; Mahmood, N.; Lau, W.-M.; Jian, X. Large-scale preparation of 2D VSe 2 through a defect-engineering approach for efficient hydrogen evolution reaction. Chem. Eng. J. 2021, 411, 128494. [CrossRef]

55. Liangruksa, M.; Sukpoonprom, P.; Junkaew, A.; Photaram, W.; Siriwong, C. Gas sensing properties of palladium-modified zinc oxide nanofilms: A DFT study. Appl. Surf. Sci. 2021, 544, 148868. [CrossRef]

56. Ni, Z.; Bao, S.; Gong, X.-Q. A DFT study of the CO adsorption and oxidation at ZnO surfaces and its implication for CO detection. Chin. Chem. Lett. 2020, 31, 1674-1679. [CrossRef] 